\title{
Integrative description of Diosaccus koreanus sp. nov. (Hexanauplia, Harpacticoida, Miraciidae) and integrative information on further Korean species
}

\author{
Byung-Jin Lim', Hyun Woo Bang², Heejin Moon², Jinwook Back' \\ I Department of Taxonomy and Systematics, National Marine Biodiversity Institute of Korea, Seocheon 33662, \\ Korea 2 Mokwon University, Daejeon, 35349, Korea \\ Corresponding author: Jinwook Back (jinwookb@mabik.re.kr)
}

Academic editor: K.H. George | Received 3 December 2019 | Accepted 2 March 2020 | Published 16 April 2020

http://zoobank.org/24272A94-472E-4F9C-836F-41D11E62C353

Citation: Lim B-J, Bang HY, Moon H, Back J (2020) Integrative description of Diosaccus koreanus sp. nov. (Hexanauplia, Harpacticoida, Miraciidae) and integrative information on further Korean species. ZooKeys 927: 1-35. https://doi.org/10.3897/zookeys.927.49042

\begin{abstract}
A new species of Diosaccus Boeck, 1873 (Arthropoda, Hexanauplia, Harpacticoida) was recently discovered in Korean waters. The species was previously recognized as D. ezoensis Itô, 1974 in Korea but, here, is described as a new species, $D$. koreanus sp. nov., based on the following features: 1 ) second inner seta on exopod of fifth thoracopod apparently longest in female, 2) outer margin of distal endopodal segment of second thoracopod ornamented with long setules in male, 3) caudal seta VII located halfway from base of rami (vs. on anterior extremity in D. ezoensis), and 4) sixth thoracopod with three setae in female (vs. 2 setae in D. ezoensis). In addition, there is also a mitochondrial COI sequence difference of more than $19.93 \%$ with D. ezoensis registered in NCBI. A key to Diosaccus species of the world is also provided, and new morphological features and DNA sequences are presented for two other harpacticoid species, Parathalestris verrucosa Itô, 1970 and Peltidium quinquesetosum Song \& Yun, 1999. In order to clearly identify harpacticoids at the species level, both morphological and DNA sequence characteristics should be considered.
\end{abstract}

\section{Keywords}

Key, mitochondrial cytochrome c oxidase subunit I, Parathalestris verrucosa, Peltidium quinquesetosum, taxonomy, $18 \mathrm{~S}$ ribonucleic acid

Copyright Byung-jin Lim et al. This is an open access article distributed under the terms of the Creative Commons Attribution License (CC BY 4.0), which permits unrestricted use, distribution, and reproduction in any medium, provided the original author and source are credited. 


\section{Introduction}

Harpacticoids (Arthropoda, Hexanauplia, Harpacticoida) are a group of benthic metazoans that are diverse in terms of both species and ecology. To date, ca 150 species of marine harpacticoids have been reported in Korean waters (Song et al. 2012). However, the diversity of harpacticoids in Korean waters is likely underestimated because many of these species have been identified on the basis of morphological characters, which are often insufficient for species identification owing to minor differences among closely-related taxa (Beheregaray and Caccone 2007; Vakati et al. 2019). In the case of Tigriopus japonicus Mori, 1938 collected from the Northwest Pacific Ocean, it is very difficult to identify its three cryptic species based on morphological characters, because there is no single morphological character that can distinguish among them (Karanovic et al. 2018). Several authors report species showing small morphological differences compared to the original descriptions, but have concluded that these are not sufficient for species differentiation (Chang 2007; Back and Lee 2011; Kim et al. 2011; Park and Lee 2011; Park et al. 2012; Kim et al. 2015). There is currently no clear way to distinguish between inter-species and intra-species differences.

In contrast to morphology-based taxonomy, recent advances in the cost and ease DNA sequencing and in the availability of public DNA sequence databases has facilitated the identification of numerous cryptic animal species (Hebert et al. 2003; Bhadury et al. 2006; DeSalle and Goldstein 2019), with the mitochondrial cytochrome c oxidase subunit I gene (COI) commonly used for species identification and the $18 \mathrm{~S}$ ribonucleic acid gene (18SrRNA) commonly used for higher-level taxonomic grouping. Yet, to define new species on the basis of DNA sequences, accurate sequences of known species are needed, and few attempts have been made to assign DNA sequences to morphologically-defined harpacticoid species. Therefore, the aim of the present study is the integrative description of a newly discovered species, and to assign DNA sequences to a morphologically-defined species, and to identify previously unrecognized taxonomically informative morphological characteristics.

\section{Material and methods}

\section{Sample collection}

The samples were all collected from Korean waters which is part of the north-western Pacific Ocean (Table 1) and fixed in $>95 \%$ ethanol. Harpacticoids were sorted from the samples using an M80 stereomicroscope (Leica, Wetzlar, Germany) and then frozen at $-20^{\circ} \mathrm{C}$.

\section{DNA extraction, amplification, sequencing, and analysis}

Each specimen was rinsed in distilled water for $15 \mathrm{~min}$ to remove ethanol and then transferred, using a sterilized pipette tip or dissection needle, to a $1.5-\mathrm{mL}$ tube that 
contained $20 \mathrm{~mL}$ Proteinase K and $180 \mathrm{~mL}$ ATL buffer for non-destructive DNA extraction (DNeasy Blood and Tissue Kit, Qiagen, Hilden, Germany). After the specimens were incubated for $3 \mathrm{~h}$ in a thermoshaker $\left(350 \mathrm{rpm}, 56^{\circ} \mathrm{C}\right)$, the $200 \mathrm{~mL}$ of lysis buffer (Proteinase K + ATL buffer) was moved to new $1.5-\mathrm{mL}$ tubes under a stereomicroscope. Each $1.5-\mathrm{mL}$ specimen tube was then filled with $70 \%$ ethanol to preserve the specimens for subsequent morphological identification and description, and DNA was isolated from the buffer samples following the protocol of the DNeasy Blood and Tissue Kit.

Both COI and $18 S r$ RNA sequences were amplified from the sample DNAs using an AccuPower HotStart PCR PreMix (Bioneer, Daejeon, South Korea), gene-specific primers (Table 2), and the amplification procedure described by Vakati et al. (2019). The resulting PCR products were sequenced in both directions using an ABI PRISM 3730XL Analyzer (Macrogen, Inc., Seoul, Korea). Sequences were assembled using Geneious 10.1.3 (Biomatters Auckland, New Zealand) (Kearse et al. 2012). Pairwise distances were calculated using the Tamura and Nei distance model (Tamura and Nei 1993) in Geneious 10.1.3. The sequences from GenBank were aligned using the Muscle algorithm integrated in Geneious 10.1.3 (Edgar 2004).

\section{Morphological characterization}

After processing for molecular analysis, each specimen was dissected on several slides using lactophenol as a mounting medium and then observed using a Leica DM2500 microscope that was equipped with a drawing tube. Descriptive terminology was adopted from Huys et al. (1996).

Abbreviations used in the text are: A1: antennule; A2: antenna; ae: aesthetasc; exp-1 $(2,3)$ : proximal (middle, distal) exopod; enp-1 $(2,3)$ : proximal (middle, distal) endopod; P1-P6: first to sixth thoracopod; seg-1(-5): first (to fifth) segment; benp: baseoendopod; mxp: maxilliped.

\section{Taxonomy}

Order Harpacticoida Sars, 1903

Family Miraciidae Dana, 1846

Genus Diosaccus Boeck, 1873

\section{Diosaccus koreanus sp. nov.}

http://zoobank.org/64547C65-0584-47D1-BEDF-AC6DDD748CB6

Figs $1-8$

Material examined. Holotype. Republic Of Korea • Ulleungdo Island; 37³1'36.56"N, 13049'41.77"E; 25 July 2017; B. Jinwook leg.; hand net, $0.5 \mathrm{~m} \cdot 1$ ㅇ (MABIK CR00247255) was dissected on 14 slides (Table 1) · GenBank accession 
Table I. Collection information of morphologically-defined harpacticoid species.

\begin{tabular}{|c|c|c|c|c|}
\hline Species & Date & Locality & Gear (depth) & Specimen nos. \\
\hline \multirow[t]{6}{*}{ Diosaccus koreanus sp. nov. } & \multirow[t]{2}{*}{ 25-07-2017 } & \multirow{2}{*}{$\begin{array}{l}37^{\circ} 31^{\prime} 36.56^{\prime \prime N}, \\
130^{\circ} 49^{\prime} 41.77^{\prime \prime} \mathrm{E}\end{array}$} & \multirow[t]{2}{*}{ hand net $(0.5 \mathrm{~m})$} & CR00247255 \\
\hline & & & & CR00247256 \\
\hline & \multirow[t]{4}{*}{$27-04-2018$} & \multirow{4}{*}{$\begin{array}{l}35^{\circ} 18^{\prime} 39.0^{\prime \prime} \mathrm{N} \\
129^{\circ} 16^{\prime} 10.6^{\prime \prime} \mathrm{E}\end{array}$} & \multirow[t]{4}{*}{ Grab $(5 \mathrm{~m})$} & CR00247257 \\
\hline & & & & CR00247258 \\
\hline & & & & CR00247259 \\
\hline & & & & CR00247260 \\
\hline Parathalestris verrucosa & 19-07-2017 & $\begin{array}{l}36^{\circ} 42^{\prime} 36.63 " \mathrm{~N} \\
129^{\circ} 28^{\prime} 31.69^{\prime \prime} \mathrm{E}\end{array}$ & light trap $(2 \mathrm{~m})$ & All specimens \\
\hline Peltidium quinquesetosum & 19-07-2017 & $\begin{array}{l}36^{\circ} 42^{\prime} 36.63 " \mathrm{~N}, \\
129^{\circ} 28^{\prime} 31.69^{\prime \prime} \mathrm{E}\end{array}$ & light trap $(2 \mathrm{~m})$ & All specimens \\
\hline
\end{tabular}

Table 2. Primer sequences and PCR conditions used in the present study.

\begin{tabular}{|c|c|c|c|c|c|c|}
\hline Gene & References & $\begin{array}{c}\text { Primer } \\
\text { name }\end{array}$ & Primer sequence & PCR condition & $\begin{array}{c}\text { Product } \\
\text { size }\end{array}$ & Species \\
\hline \multirow{3}{*}{$\begin{array}{l}\mathrm{mt} \\
\mathrm{COI}\end{array}$} & \multirow{3}{*}{$\begin{array}{c}\text { Folmer et al. } \\
\text { (1994) }\end{array}$} & LCO1490 & GGTCAACAAATCATAAAGATATTGG & \multirow{3}{*}{$\begin{array}{c}94^{\circ} \mathrm{C}, 300 \mathrm{~s} \\
40 \text { cycles } \times\left(94^{\circ} \mathrm{C} \text {, }\right. \\
60 \mathrm{~s} ; 46^{\circ} \mathrm{C}, 120 \\
\mathrm{~s} ; 72^{\circ} \mathrm{C}, 180 \mathrm{~s} \\
\left.72^{\circ} \mathrm{C}, 600 \mathrm{~s}\right)\end{array}$} & \multirow{3}{*}{$\begin{array}{l}658 \\
658 \\
661\end{array}$} & \multirow{3}{*}{$\begin{array}{c}\text { D. koreanus sp. nov } \\
\text { Pa. verrucosa } \\
\text { Pe. quinquesetosum }\end{array}$} \\
\hline & & (universal) & & & & \\
\hline & & $\begin{array}{c}\mathrm{HCO} 2198 \\
\text { (universal) }\end{array}$ & TAAACTTCAGGGTGACCAAAAAATCA & & & \\
\hline \multirow[t]{8}{*}{$\begin{array}{l}18 S \\
\text { rRNA }\end{array}$} & $\begin{array}{l}\text { Yamaguchi } \\
\text { (2003) }\end{array}$ & $\begin{array}{c}18 \mathrm{SF} 1 \\
\text { (universal) }\end{array}$ & TACCTGGTTGATCCTGCCAG & $\begin{array}{c}94^{\circ} \mathrm{C}, 300 \mathrm{~s} \\
40 \text { cycle } \times\left(94{ }^{\circ} \mathrm{C}\right. \\
30 \mathrm{~s} ; 50^{\circ} \mathrm{C}, 30 \\
\left.\mathrm{~s} ; 72^{\circ} \mathrm{C}, 60 \mathrm{~s}\right) \\
72^{\circ} \mathrm{C}, 420 \mathrm{~s}\end{array}$ & 1,756 & D. koreanus sp. nov \\
\hline & & $\begin{array}{c}\text { 18SR9 } \\
\text { (universal) }\end{array}$ & GATCCTTCCGCAGGTTCACCTAC & & 1,761 & Pa. verrucosa \\
\hline & & $\begin{array}{c}18 \mathrm{SF} 2 \\
\text { (internal) }\end{array}$ & CCTGAGAAACGGCTRCCACAT & \multirow{6}{*}{$\begin{array}{l}\text { These primers } \\
\text { were used for } \\
\text { primer walking } \\
\text { to sequence over } \\
1700 \mathrm{bp}\end{array}$} & \multirow[t]{6}{*}{1,763} & \multirow[t]{6}{*}{ Pe. quinquesetosum } \\
\hline & & $\begin{array}{c}18 \mathrm{SF} 3 \\
\text { (internal) }\end{array}$ & GYGRTCAGATACCRCCSTAGTT & & & \\
\hline & & $\begin{array}{c}18 \mathrm{SF} 4 \\
\text { (internal) }\end{array}$ & GGTCTGTGATGCCCTYAGATGT & & & \\
\hline & & $\begin{array}{c}18 \mathrm{SR} 6 \\
\text { (internal) }\end{array}$ & TYTCTCRKGCTBCCTCTCC & & & \\
\hline & & $\begin{array}{c}\text { 18SR7 } \\
\text { (internal) }\end{array}$ & GYYARAACTAGGGCGGTATCTG & & & \\
\hline & & $\begin{array}{c}18 \mathrm{SR} 8 \\
\text { (internal) }\end{array}$ & ACATCTRAGGGCATCACAGACC & & & \\
\hline
\end{tabular}

number for COI sequence: MN996281. Paratypes. Republic Of Korea (Table 1) - 1 ๙ (MABIK CR00247257) was dissected on 8 slides and observed . 4 우 (MABIK CR00247256, CR00247258 - CR00247260) were preserved in 99\% alcohol . GenBank accession numbers: MN996277 to MN996280 (COI) and MT002900 to MT002902 (18SrRNA).

Description. Female. Body (Figs 1, 2): Total length, from anterior margin of rostrum to posterior margin of caudal rami, $1135 \mu \mathrm{m}(N=5$, mean $=1133 \mu \mathrm{m}$; Fig. 1$)$; 


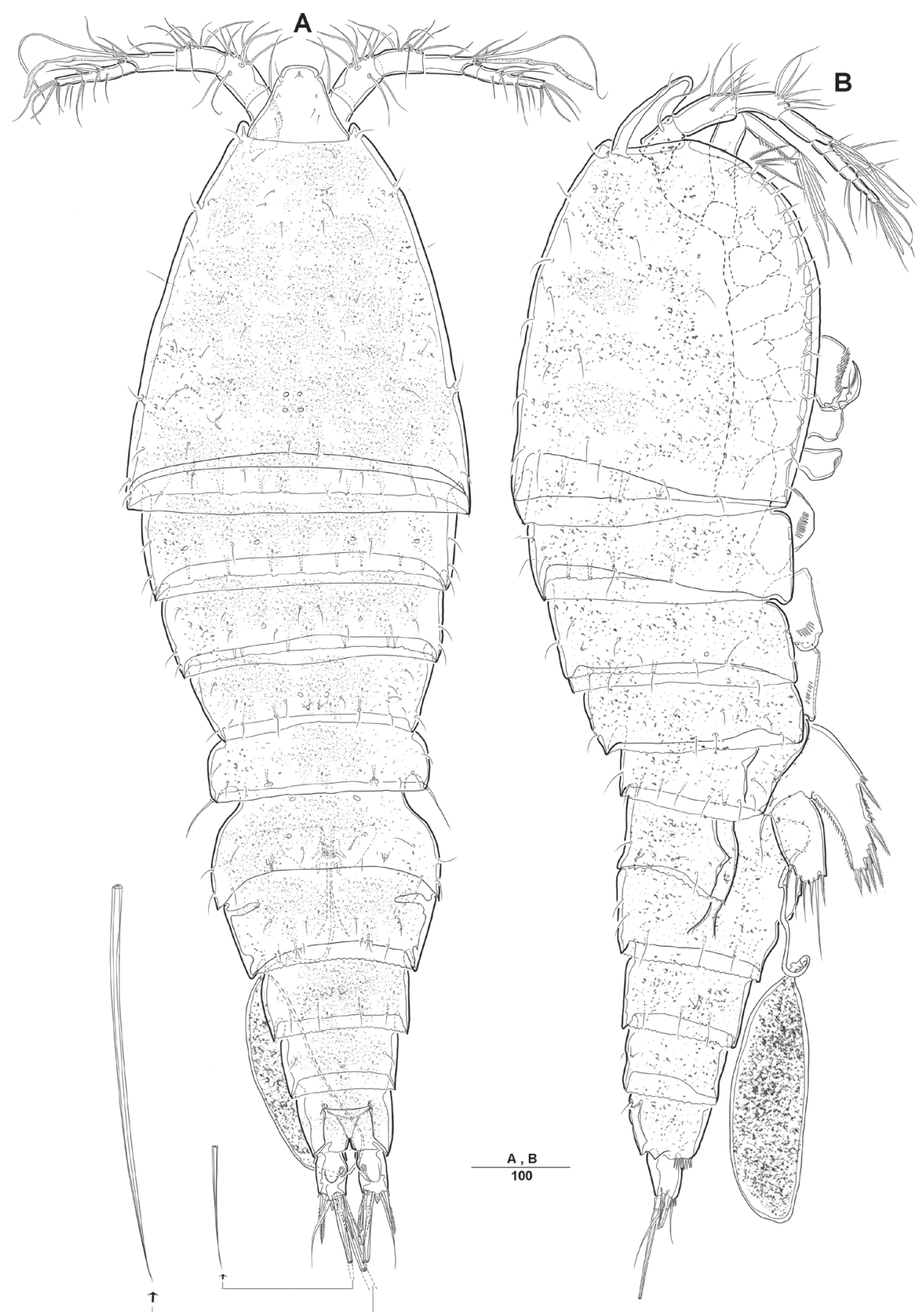

Figure I. Diosaccus koreanus sp. nov., female A habitus, dorsal B habitus, lateral. Scale bars indicate length in $\mu \mathrm{m}$. 


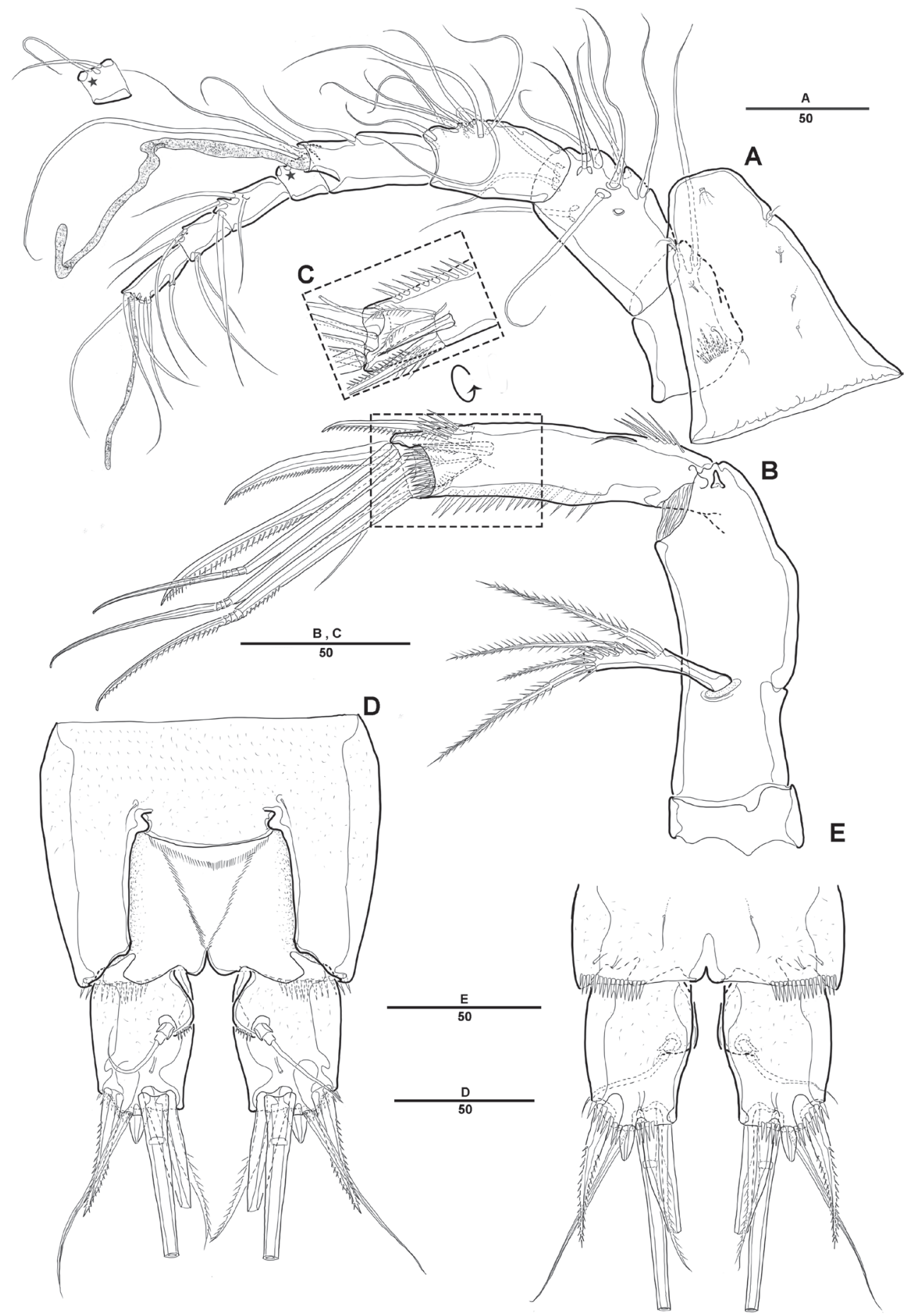

Figure 2. Diosaccus koreanus sp. nov., female $\mathbf{A}$ rostrum and antennule, dorsal $\mathbf{B}$ antenna $\mathbf{C}$ end of antennary endopod $\mathbf{D}$ caudal rami, dorsal $\mathbf{E}$ caudal rami, ventral. Scale bars indicate length in $\mu \mathrm{m}$. 
maximum width $340 \mu \mathrm{m}$, measured at distal cephalothorax; body cylindrical, not dorsoventrally depressed, and with minute dorsal sensilla; rostrum well developed, defined at base, trapezoid in shape, with round apex and 2 sensilla (Figs 1A, 2A); cephalothorax sub-triangle with sensilla and smooth margin; second and third urosomites fully fused ventrally, but with transverse ridge on dorsal and lateral surfaces indicating original segmentation (Figs 1A, B, 6B); anal operculum not well developed, with spinular tuft (Fig. 2D).

Caudal rami (Fig. 2D, E): Parallel, ca 1.5 times longer than maximum width, dorsal surface with small bumps; each ramus with 7 setae: seta I strong, pinnate; setae II bare on distal corner; seta III blunt spine; setae IV and V strong; seta VI pinnate; seta VII bare, triarticulate at base.

$\boldsymbol{A 1}$ (Fig. 2A): Slender, 8-segmented; seg-2 longest, ca 1.2 times as long as seg-3; seg-4 with sub-cylindrical pedestal armed with aesthetasc fused at base to 1 long bare seta; armature formula: 1-[1], 2-[11], 3-[9], 4-[3 + (1+ae)], 5-[2], 6-[4], 7-[4], 8[3+acrothek]; apical acrothek of short aesthetasc fused basally to 2 bare setae.

A2 (Fig. 2B, C): 3-segmented, with coxa, allobasis, and free 1-segmented enp; coxa small and bare; allobasis without abexopodal seta; exp 1-segmented, with 2 lateral and 2 apical pinnate setae; free enp with 2 pinnate setae and 2 long spines laterally and with 1 bare seta, 2 spines, and 3 geniculate setae along distal margin.

Mandible (Fig. 3A): Gnathobase with several blunt teeth; palp basis with 2 inner pinnate setae; exp 1-segmented with 2 pinnate distal setae; enp with 2 lateral and 6 distal setae.

Maxillule (Fig. 3B, C): Praecoxa trapezoidal in shape, without ornamentation; arthrite well developed, with 2 juxtaposed setae near midpoint of anterior surface, 4 strong teeth-like spines and 3 tuft spines along distal margin; coxa fused with cylindrical endite, with 1 pinnate seta; basis fused with endite, with 1 bare and 5 pinnate setae; exp 1-segmented, with 2 pinnate setae distally; enp 1-segmented, with 4 pinnate setae along distal margin.

Maxilla (Fig. 3D): Syncoxa with 2 endites; proximal endite with 2 strong spines and 1 bare seta among distal margin; second endite with 1 strong spine, 1 bare seta, and 1 tuft-like seta; allobasis developed into cylindrical process, with 2 strong spines and 2 bare setae; enp 1-segmented, with 2 bare and 3 pinnate setae.

$\operatorname{Mxp}$ (Fig. 3E): 4-segmented, with syncoxa, basis, and 2-segmented enp; syncoxa with 2 pinnate setae distally; basis elongate and robust, with 2 small bare setae (Fig. 3E, arrow) and roughly ornamented with rows of spinules along inner margin; enp-1 with 1 bare and 1 pinnate setae; enp-2 forming strong claw ornamented with row of spinules among inner proximal half.

Swimming legs (Figs 4, 5): Biramous; P1-P4 with coxa, basis, and 3-segmented exp and enp; each ramus ornamented with setules or spinules along outer margins as figured.3

P1 (Fig. 4A, B): Coxa ornamented with inner spinules; basis with 1 outer and 1 inner pinnate setae; exp- 1 with 1 outer spine; exp- 2 with 1 outer spine and 1 inner pin- 

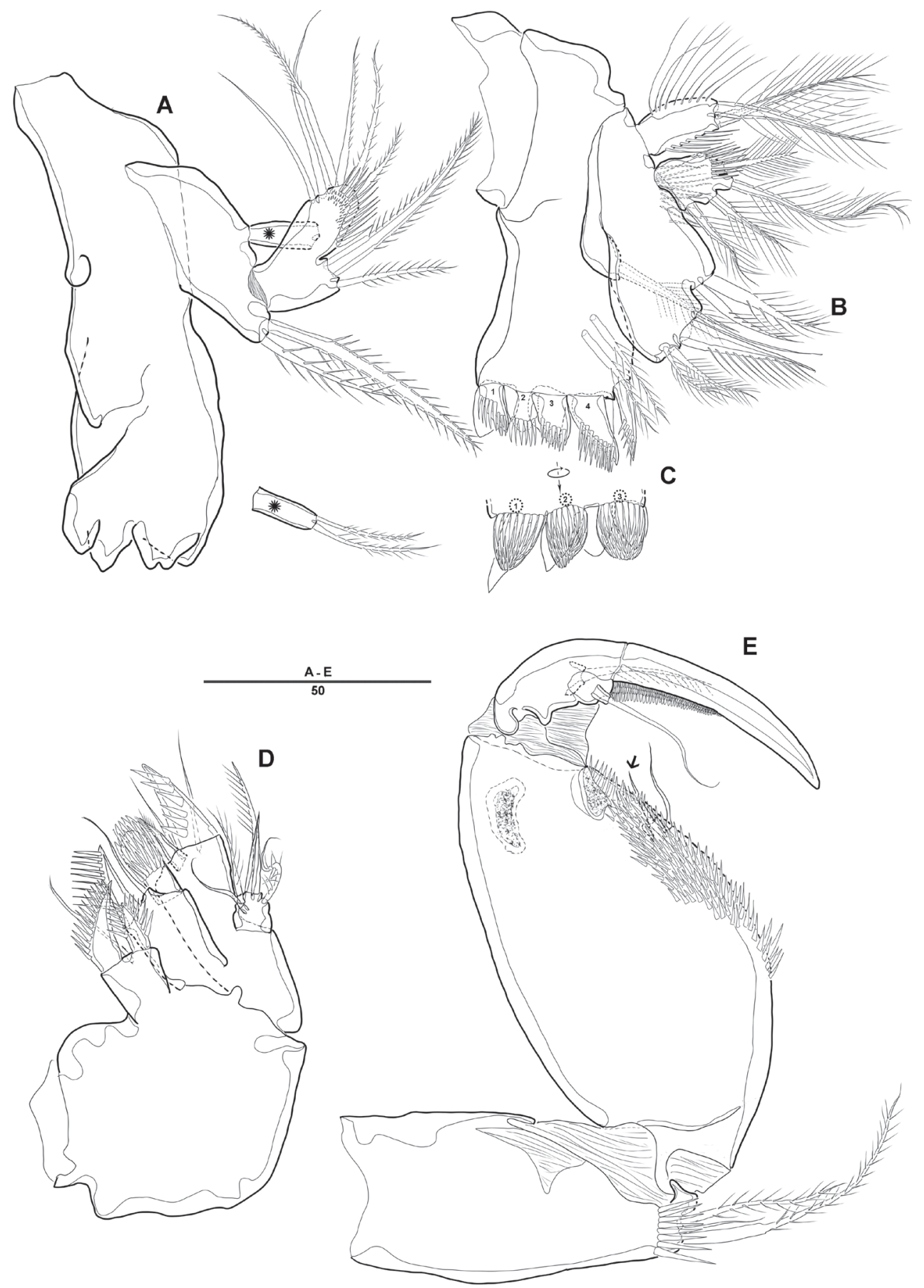

Figure 3. Diosaccus koreanus sp. nov., female A mandible B maxillule $\mathbf{C}$ shape of elements in praecoxal arthrite of maxillule $\mathbf{D}$ maxilla $\mathbf{E}$ maxilliped. Scale bars indicate length in $\mu \mathrm{m}$. 


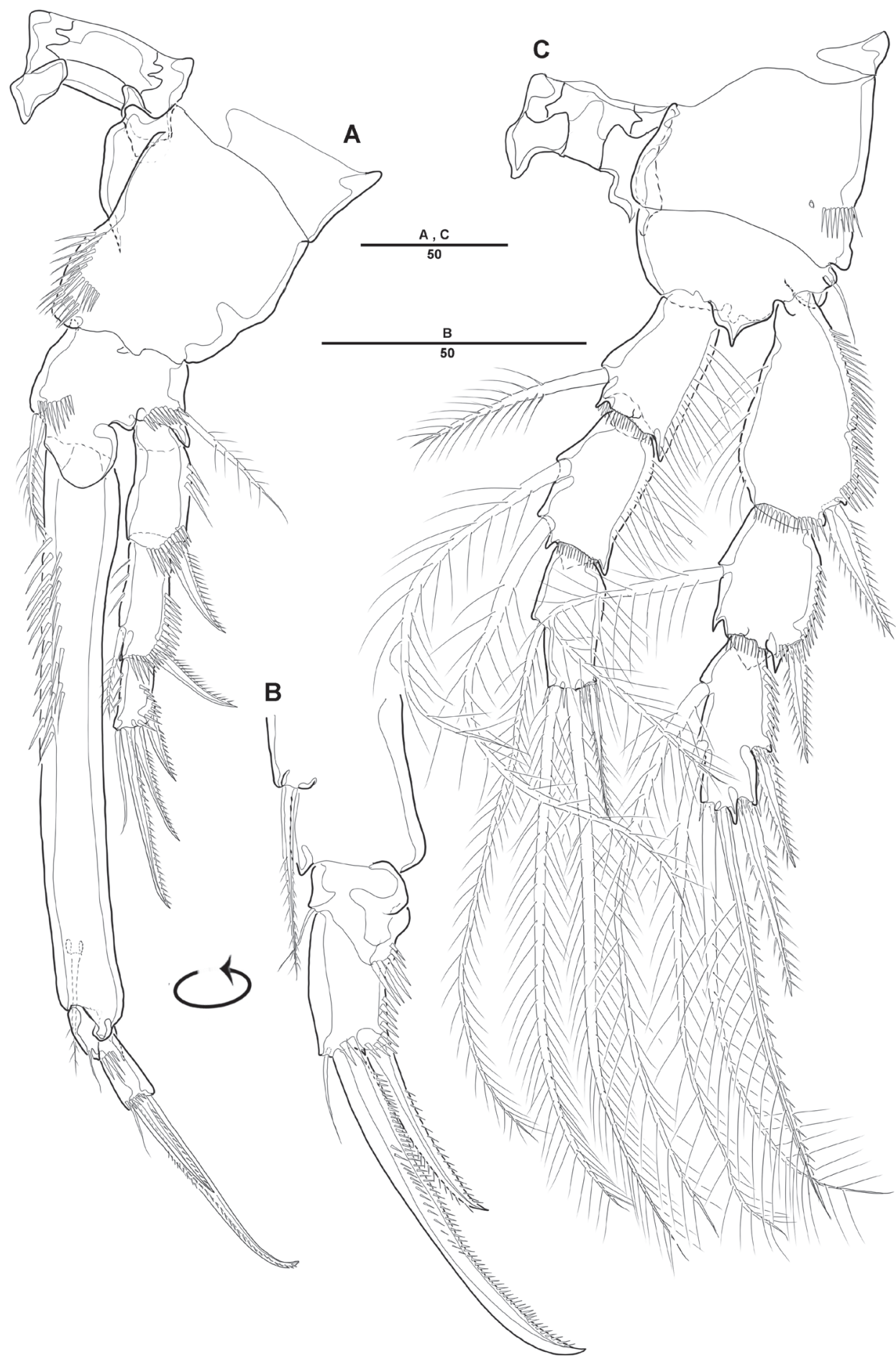

Figure 4. Diosaccus koreanus sp. nov., female $\mathbf{A}$ first thoracopod $\mathbf{B}$ middle and distal endopods of first thoracopod $\mathbf{C}$ second thoracopod. Scale bars indicate length in $\mu \mathrm{m}$. 


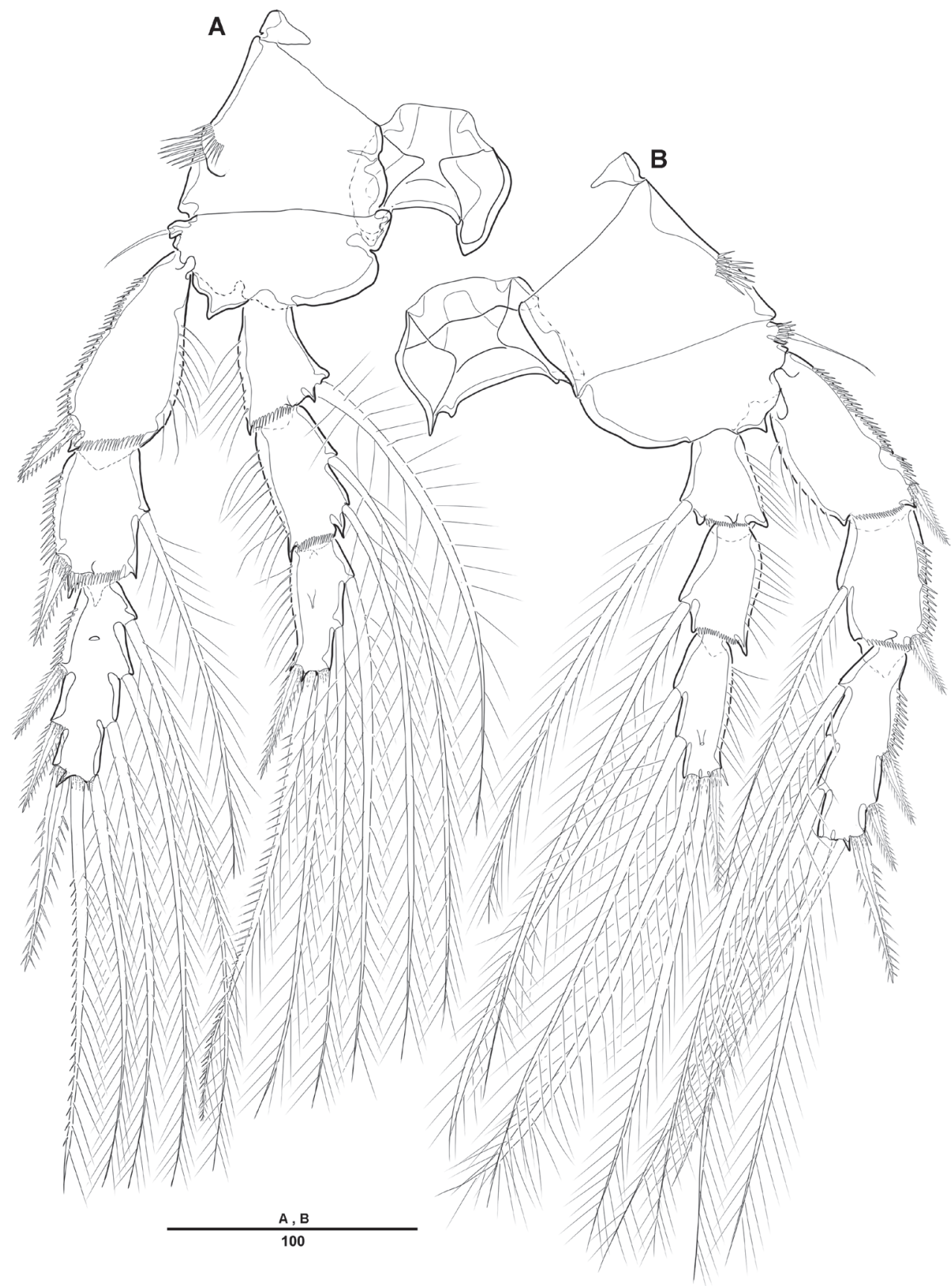

Figure 5. Diosaccus koreanus sp. nov., female $\mathbf{A}$ third thoracopod B fourth thoracopod. Scale bars indicate length in $\mu \mathrm{m}$. 
nate seta; exp-3 with 3 spines and 1 bare seta; enp- 1 ornamented with row of spinules on inner proximal half, ca 2 times longer than exp, with 1 pinnate seta; enp- 2 with 1 small bare seta on inner distal corner, enp-3 with 2 strong spines distally and 1 bare seta near inner distal corner.

P2 (Fig. 4C): Coxa ornamented with row of spinules on outer margin; basis with 1 outer bare seta near distal corner; exp-1 with 1 outer spine, ornamented with a row of long setules along inner margin; exp-2 with 1 outer spine and 1 inner pinnate seta, ornamented with row of setules along outer margin; exp-3 with 2 outer spines and 2 apical and 2 inner pinnate setae; enp- 1 with 1 inner pinnate seta, ornamented with long setules along outer margin; enp- 2 with 2 pinnate inner setae; enp-3 with 1 outer, 2 distal, and 1 inner pinnate setae.

P3-P4 (Fig. 5A, B): Coxa ornamented with rows of spinules on outer margin; basis with 1 outer bare seta near distal corner; exp-1 with 1 outer spine, ornamented with row of long setules along inner margin; exp-2 with 1 outer spine and 1 inner pinnate seta, ornamented with row of spinules along outer margin; exp-3 with 3 outer spines, 2 apical and 3 inner pinnate setae; enp- 1 with 1 inner seta, ornamented with long setules among outer margin; enp-2 with 2 inner pinnate setae [P3] or 1 inner pinnate seta [P4]; enp-3 with 1 outer spine, 2 apical pinnate and 2 inner pinnate setae.

Armature formulae as follows:

\begin{tabular}{lcc}
\hline & Exopod & Endopod \\
\hline P1 & 0.1 .112 & 1.1 .120 \\
P2 & 0.1 .222 & 1.2 .121 \\
P3 & 0.1 .323 & 1.2 .221 \\
P4 & 0.1 .323 & 1.1 .221 \\
\hline
\end{tabular}

P5 (Fig. 6C): Defined at supporting somite; each side of endopodal lobe separated, with 6 spine-like setae; exp with 6 setae, second inner element longest.

P6 (Fig. 6A, B): Fused with supporting somite, with 3 bare setae, innermost seta longest.

Male. Body (Fig. 7A): Total length, from anterior margin of rostrum to posterior margin of caudal rami, $880 \mu \mathrm{m}$; maximum width $262 \mu \mathrm{m}$, measured at distal cephalothorax; general body shape, ornamentation, and sensilla pattern almost identical to those of female, but with sexual dimorphisms observed in A1, P1, P2, P5, P6, and genital somites.

$\boldsymbol{A 1}$ (Fig. 8C, D): Subchirocer 10-segmented, robust; seg-3 with aesthetasc fused at base to 1 bare seta; seg- 5 swollen, with aesthetasc fused at base to 1 bare seta; armature formula: 1-[1], 2-[10], 3- [4+(1+ae)], 4-[2], 5-[4+(1+ae)], 6-[2 bare], 7-[1], 8-[1], 9-[4], 10-[5+(1+ae)].

P1 (Fig. 8A): General shape of P1 similar to that of female, except basis; basis with 1 outer pinnate seta and 1 wrinkled process near base of outer seta.

P2 (Fig. 8B): Enp 2-segmented; enp-1 with 1 inner bare seta and ornamented with row of long setules along outer margin; enp-2 with 1 inner bare seta on small disk 
B

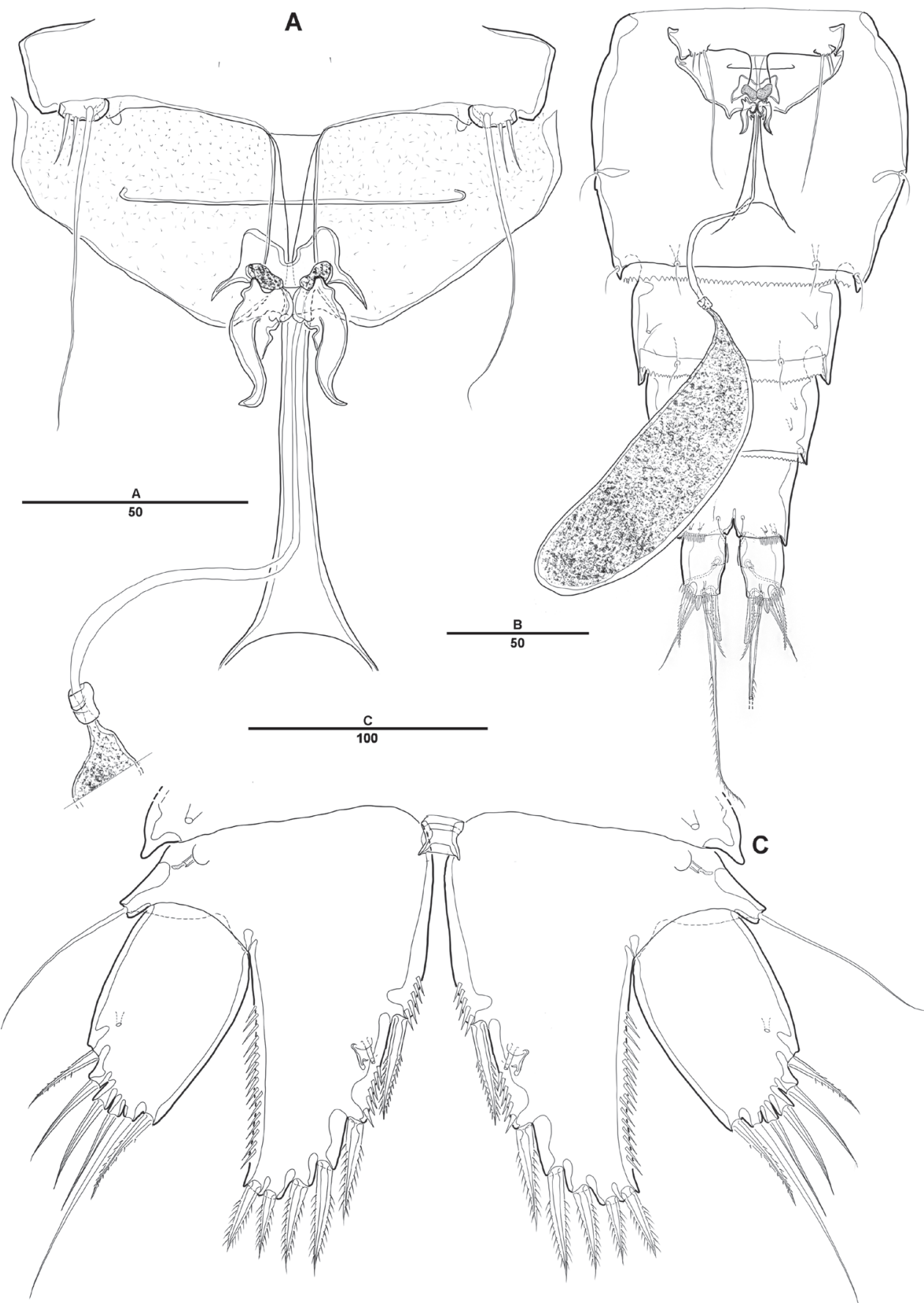

Figure 6. Diosaccus koreanus sp. nov., female $\mathbf{A}$ sixth thoracopod and genital field $\mathbf{B}$ urosomites, ventral C fifth thoracopod. Scale bars indicate length in $\mu \mathrm{m}$. 


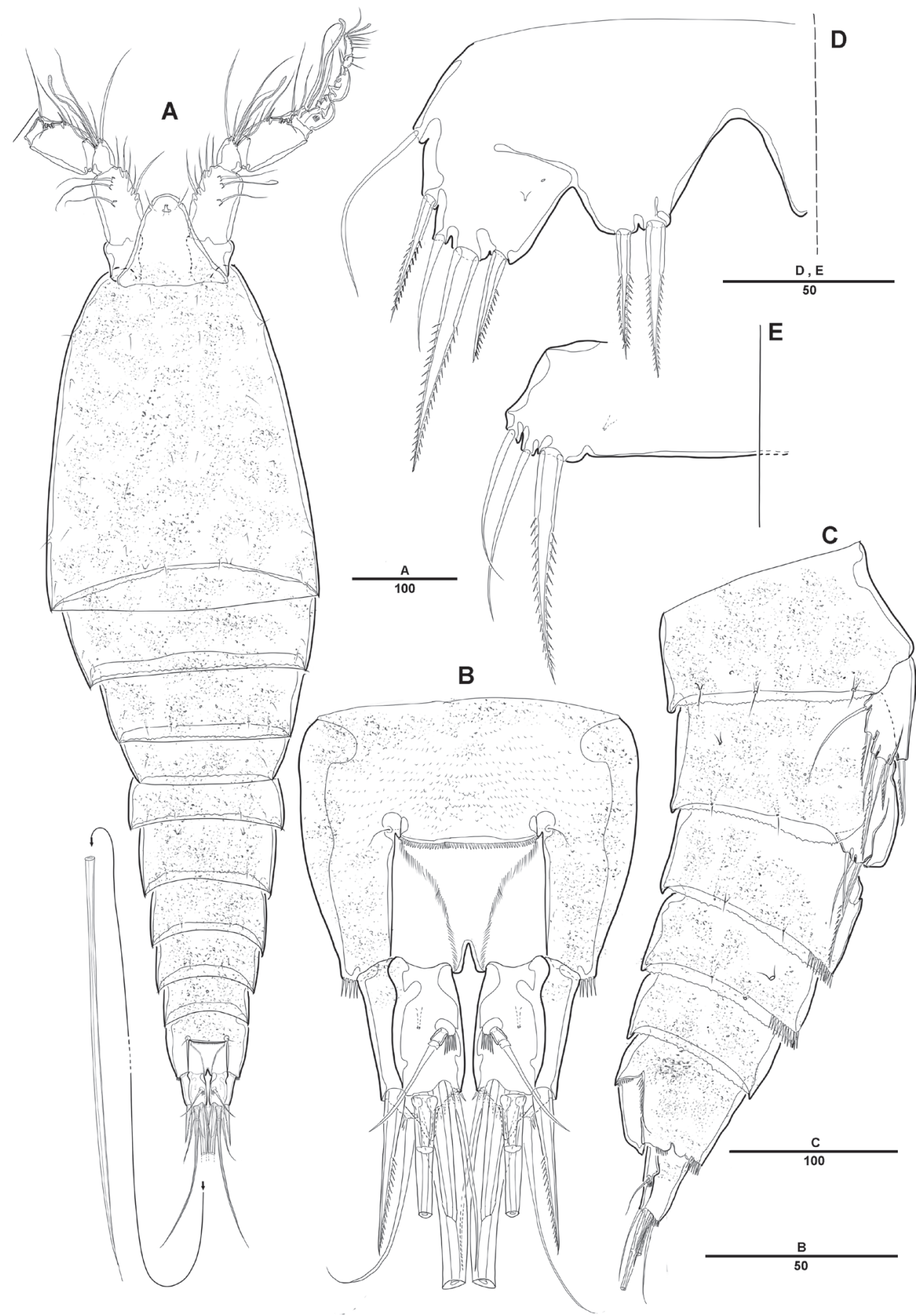

Figure 7. Diosaccus koreanus sp. nov., male A habitus, dorsal B caudal rami, dorsal C urosomites, lateral D fifth thoracopod E sixth thoracopod. Scale bars indicate length in $\mu \mathrm{m}$. 


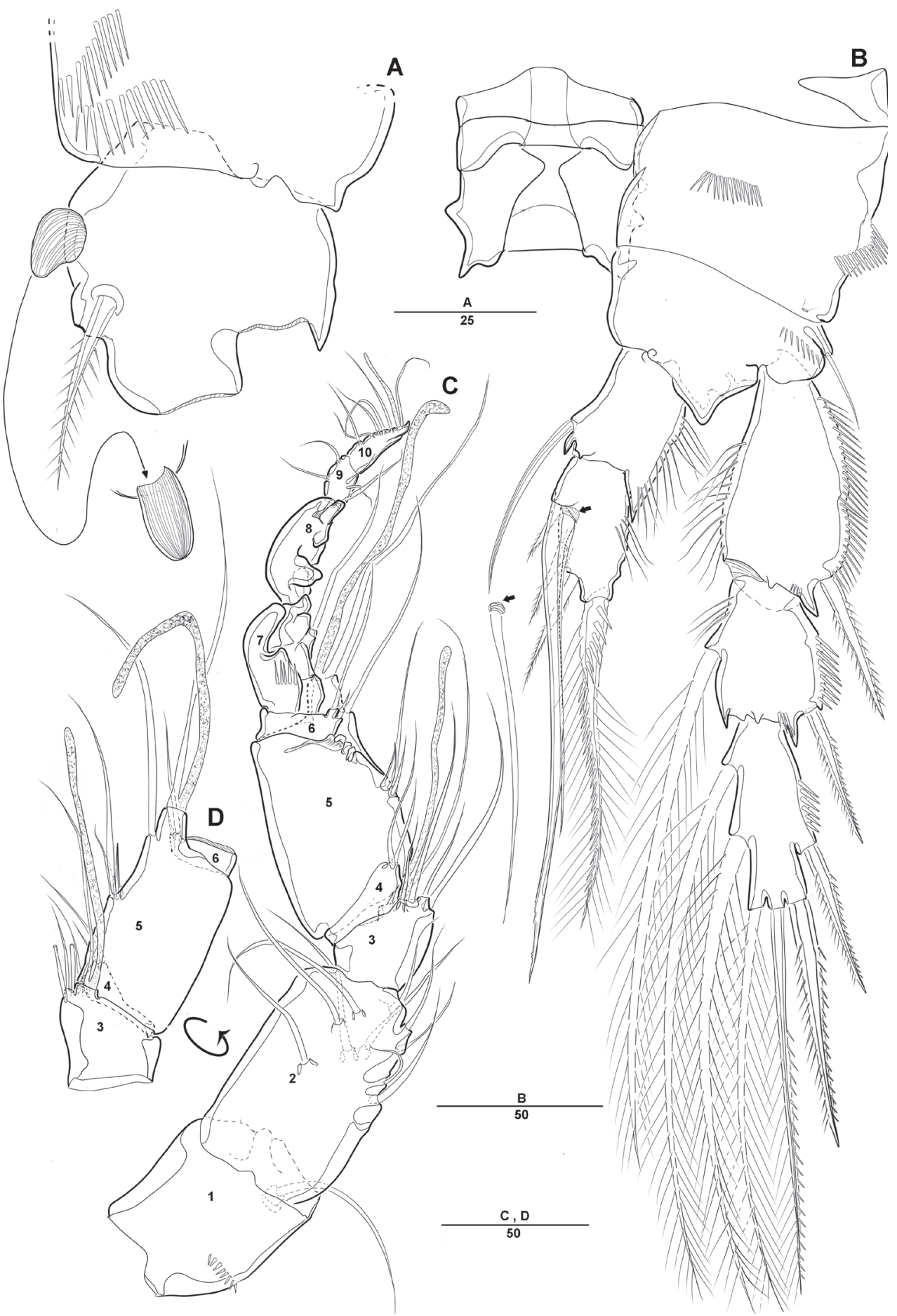

Figure 8. Diosaccus koreanus sp. nov., male $\mathbf{A}$ base of first thoracopod $\mathbf{B}$ second thoracopod $\mathbf{C}$ antennule D antennule segments 3-6. Scale bars indicate length in $\mu \mathrm{m}$. 
Table 3. Pairwise distances (Tamura-Nei distance) between COI sequences from species in genus Diosaccus. Numbers in parentheses indicate the Genbank accession numbers.

\begin{tabular}{|c|c|c|c|c|c|c|c|c|c|}
\hline & & 1 & 2 & 3 & 4 & 5 & 6 & 7 & 8 \\
\hline 1 & $\begin{array}{l}\text { D. koreanus sp. nov. } \\
\text { (CR00247255, CR00247258) }\end{array}$ & & & & & & & & \\
\hline 2 & $\begin{array}{l}\text { D. koreanus sp. nov. } \\
\text { (CR00247256) }\end{array}$ & 1.52 & & & & & & & \\
\hline 3 & $\begin{array}{l}\text { D. koreanus sp. nov. } \\
\text { (CR00247257 CR00247260) }\end{array}$ & 0.91 & 0.91 & & & & & & \\
\hline 4 & $\begin{array}{l}\text { D. koreanus sp. nov. } \\
\text { (CR00247259) }\end{array}$ & 2.28 & 1.67 & 1.67 & & & & & \\
\hline 5 & D. ezoensis (KR049013) & 19.93 & 20.62 & 20.62 & 20.79 & & & & \\
\hline 6 & D.spinatus (MH242730) & 20.36 & 21.28 & 21.28 & 22.04 & 19.76 & & & \\
\hline 7 & D.spinatus (MH242731) & 20.67 & 21.59 & 21.59 & 22.34 & 19.42 & 1.06 & & \\
\hline 8 & D.spinatus (HQ966504) & 20.06 & 20.97 & 20.97 & 21.73 & 19.93 & 1.06 & 0.61 & \\
\hline
\end{tabular}

Table 4. Pairwise distances (Tamura-Nei distance) based on 1,756 bp between $18 \operatorname{SrRNA}$ sequences from species in genus Diosaccus.

\begin{tabular}{lllll}
\hline \multicolumn{1}{c}{ Species (Genbank accession number) } & $\mathbf{1}$ & $\mathbf{2}$ & $\mathbf{3}$ \\
\hline 1 & Diosaccus koreanus sp. nov (MT002900 - MT002902) & & & \\
2 & D. ezoensis (KR048740) & 1.46 & & \\
3 & Diosaccus sp. (EU380290) & 7.24 & 8.55 & \\
\hline
\end{tabular}

(Fig. 8B, arrow) of which middle inner edge and 1 longest bare seta, 3 pinnate inner setae, and 1 strong spinulose seta apically.

P5 (Fig. 7D): Fused medially; plate of benp fused each side; basal part with 1 bare seta; endopodal lobe with 2 spinulose pinnate setae; exp fused at base, with 3 spinulose setae and 1 bare seta.

P6 (Fig. 7E): Fused at base, with 2 bare and 1 spinulose setae.

Etymology. Species name refers to the type locality (i.e., Republic of Korea).

DNA sequences. In regards to pairwise distances (Tamura-Nei distance) among the 582-bp COI sequences, $D$. koreanus sp. nov. exhibited intra-specific variation of $0-2.28 \%$, and inter-specific distances of $19.42-22.34 \%$ were observed among all three Diosaccus species (Table 3). In regards to the $18 \operatorname{SrRNA}$ sequences, intra- and interspecific variations of $0 \%$ and $1.46-8.55 \%$ were observed (Table 4).

Family Thalestridae Sars G.O., 1905

Genus Parathalestris Brady \& Robertson D., 1873

Parathalestris verrucosa Itô, 1970

Figs 9-15

Material examined. Republic Of Korea 1 o (MABIK CR00246555) was dissected on 13 slides $\cdot 1$ ऽ (MABIK CR00246552) was dissected on 9 slides $\cdot 11$ 우 


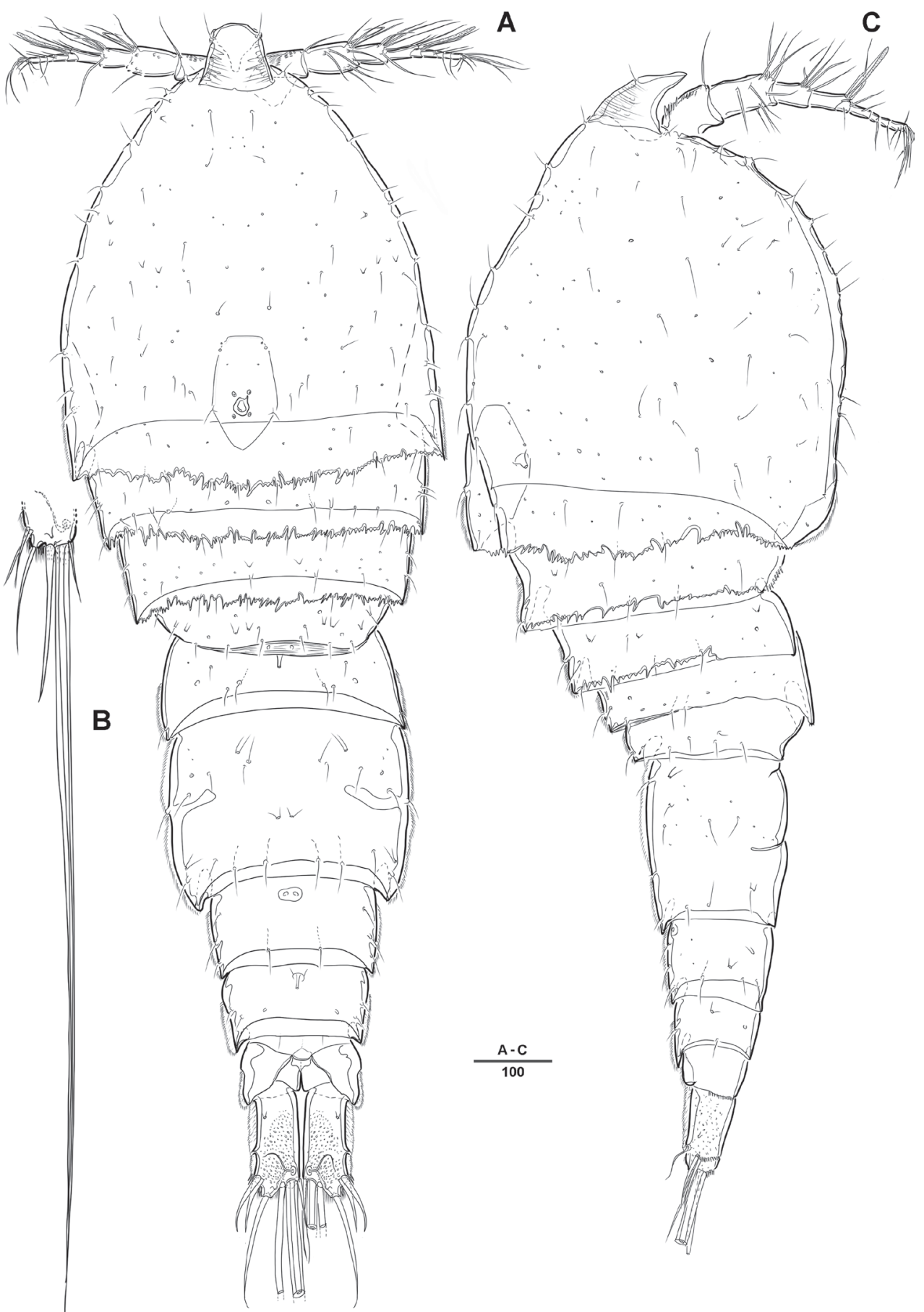

Figure 9. Parathalestris verrucosa Itô, 1970, female A habitus, dorsal B end of caudal rami C habitus, lateral. Scale bars indicate length in $\mu \mathrm{m}$. 
(MABIK CR00246553, CR00246554, CR00246556 to CR00246560, CR00246562 to CR00246565) and 1 त (MABIK CR00246561) were preserved in $99 \%$ alcohol . GenBank accession numbers: MN996282 to MN996293 (COI) and MT002906 to MT002909 (18SrRNA).

Description. Parathalestris verrucosa Itô, 1970 (p. 211-218, Figs 1-4), see also Chang and Song (1997).

Note. Chang and Song (1997) reported that P. verrucosa collected from Korea differed from Itô’s description in regards to three characteristics (length of caudal rami, segmentation of A2 exp, and presence of rows of spines along posteroventral margin), and the specimens analyzed in the present study also varied in this manner. In particular, the base of the second lateral seta of the A2 exp was protruding and could be seen as two segments, depending on the angle. In addition, the male specimens analyzed in the present study also differed from Itôs original description in regards to A1 segmentation. More specifically, the A1 of Itôs specimen possessed a small seg-3 and swollen seg-4, whereas that of the present study's specimens possessed small seg- 3 and seg- 4 and a swollen seg- 5 .

\section{Family Peltidiidae Claus, 1860 \\ Genus Peltidium Philippi, 1839}

Peltidium quinquesetosum Song \& Yun, 1999

Figs $16-22$

Peltidium quinquesetosum Song \& Yun, 1999: 67-74, figs 1-3

Material examined. Republic Of Korea (Table 1) 1 q (MABIK CR00246774) was dissected on 10 slides 19 (MABIK CR00246775) was dissected on 6 slides 1 $\widehat{\partial}$ (MABIK CR00246787) was dissected on 10 slides 11 우 (MABIK CR00246776 to CR00246786) were preserved in 99\% alcohol . GenBank accession numbers: MT006218 to MT006229 (COI) and MT002903 to MT002905 (18SrRNA).

Note. There was no remarkable difference between the original description and the specimens analyzed in the present study. However, additional details of sensilla on the surface, the structure of mouthparts and appendages, and the rows of spinules and setules were added in the figures.

\section{Discussion}

\section{Relationships among Diosaccus spp.}

The new species (D. koreanus sp. nov.) was placed in the genus Diosaccus on the basis of several characteristics (A2 exp with 4 setae, P2 exp-2 with 2 inner setae, P2 exp-1 without inner seta, and $\mathrm{P} 4$ enp 3 -segmented) and was most closely related to D. ezoensis 


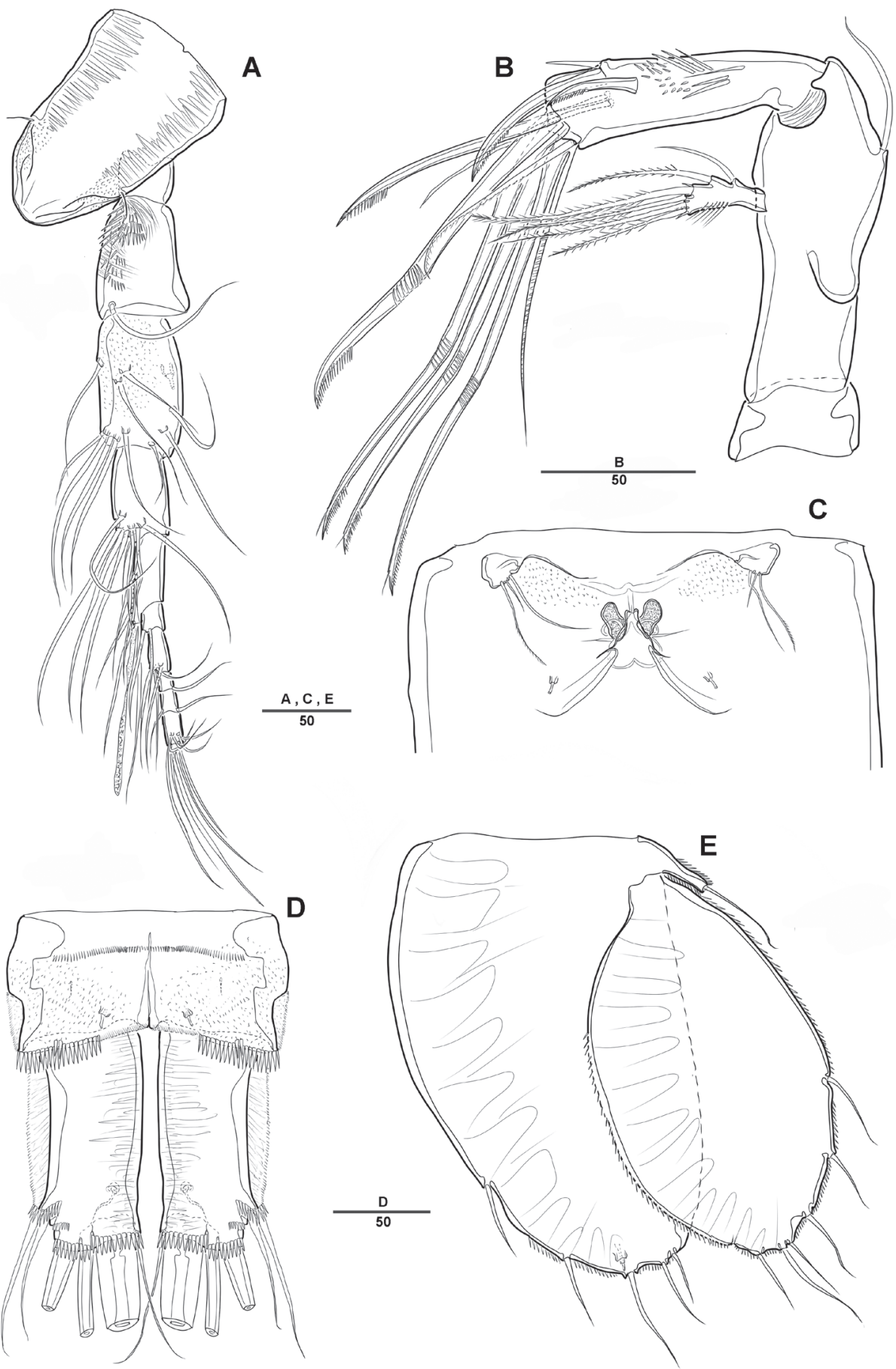

Figure 10. Parathalestris verrucosa Itô, 1970, female A rostrum and antennule B antenna C sixth thoracopod and genital field D caudal rami, ventral E fifth thoracopod. Scale bars indicate length in $\mu \mathrm{m}$. 


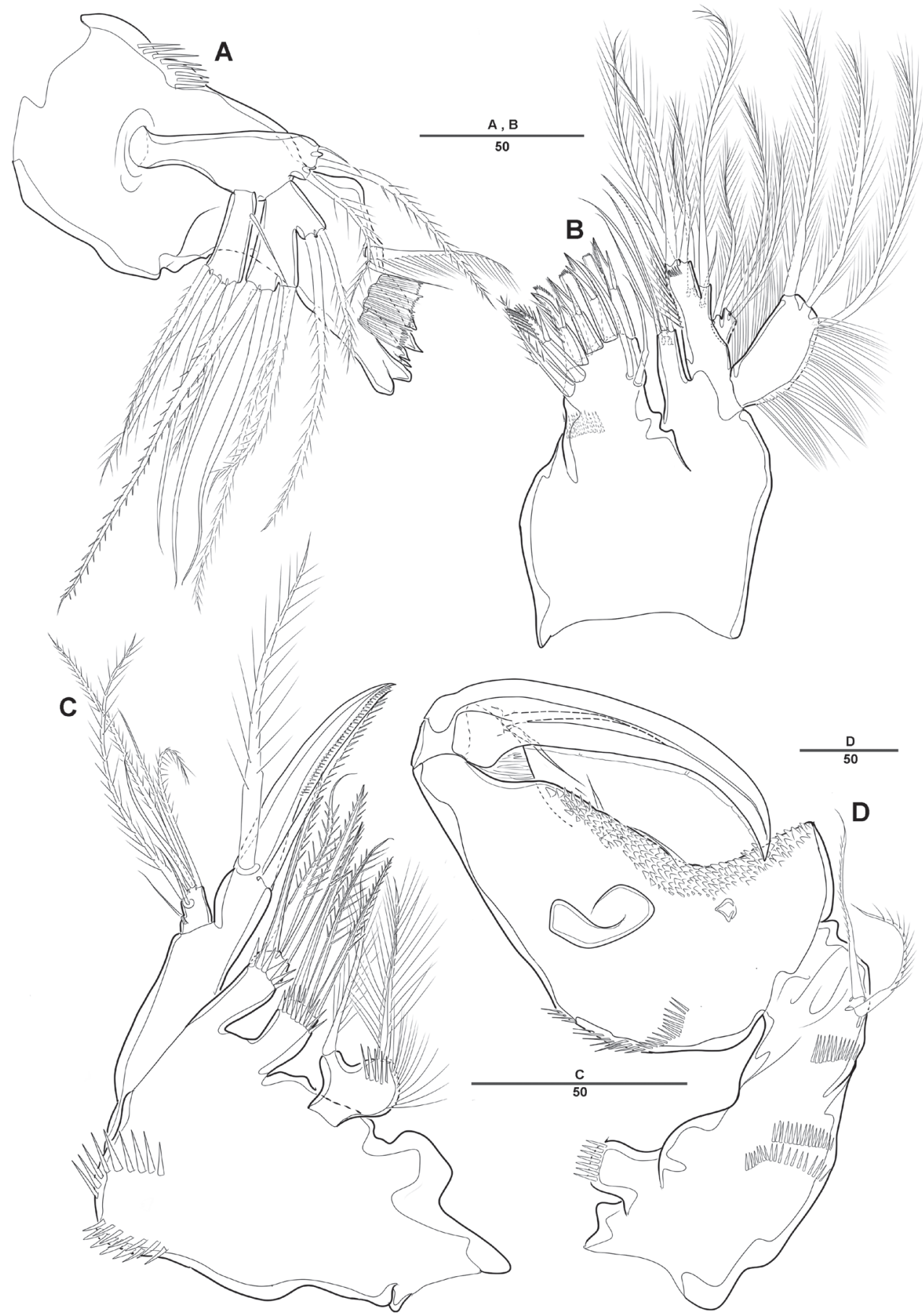

Figure II. Parathalestris verrucosa Itô, 1970, female A mandible B maxillule C maxilla D maxilliped. Scale bars indicate length in $\mu \mathrm{m}$. 


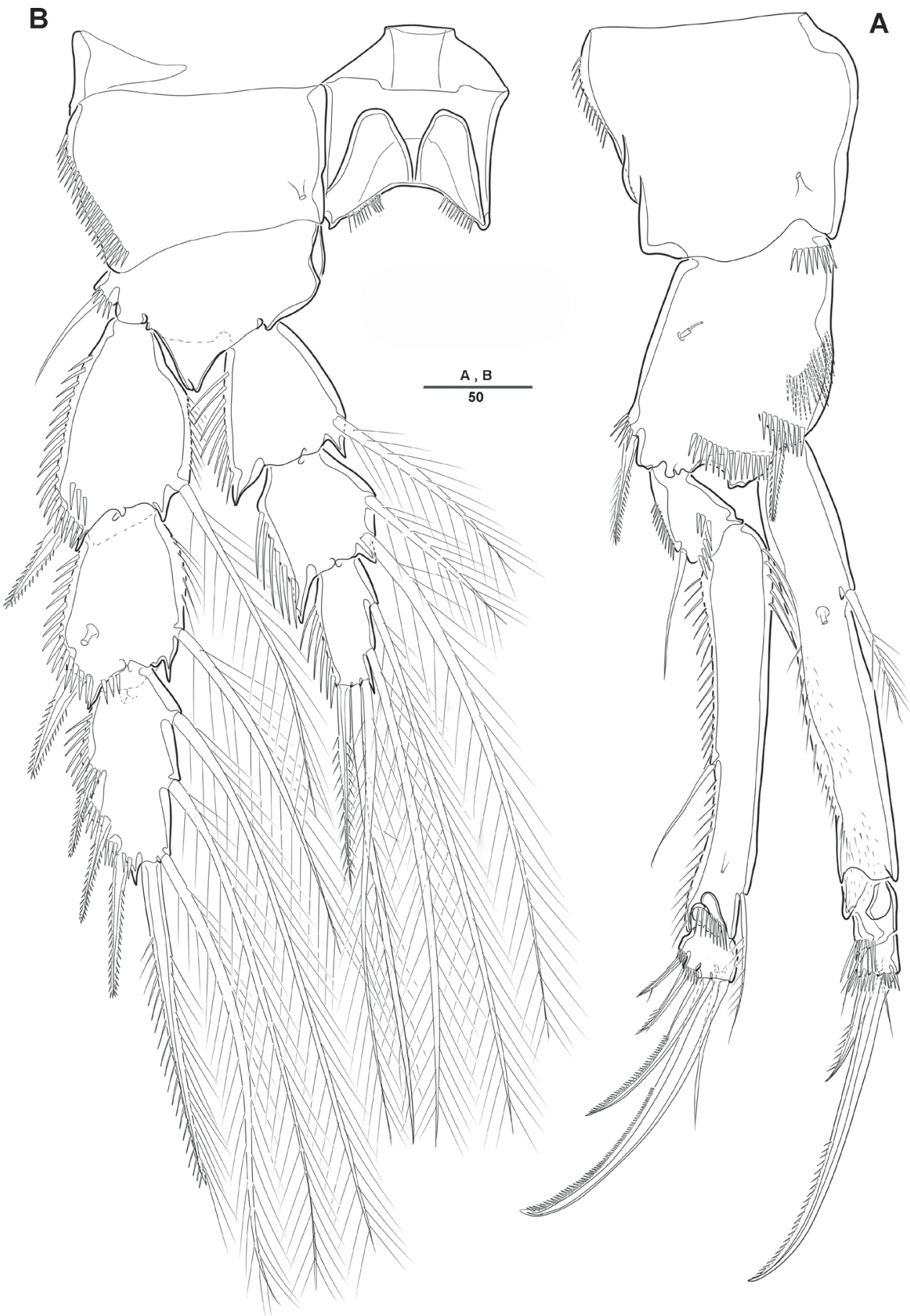

Figure 12. Parathalestris verrucosa Itô, 1970, female A first thoracopod B second thoracopod. Scale bars indicate length in $\mu \mathrm{m}$. 


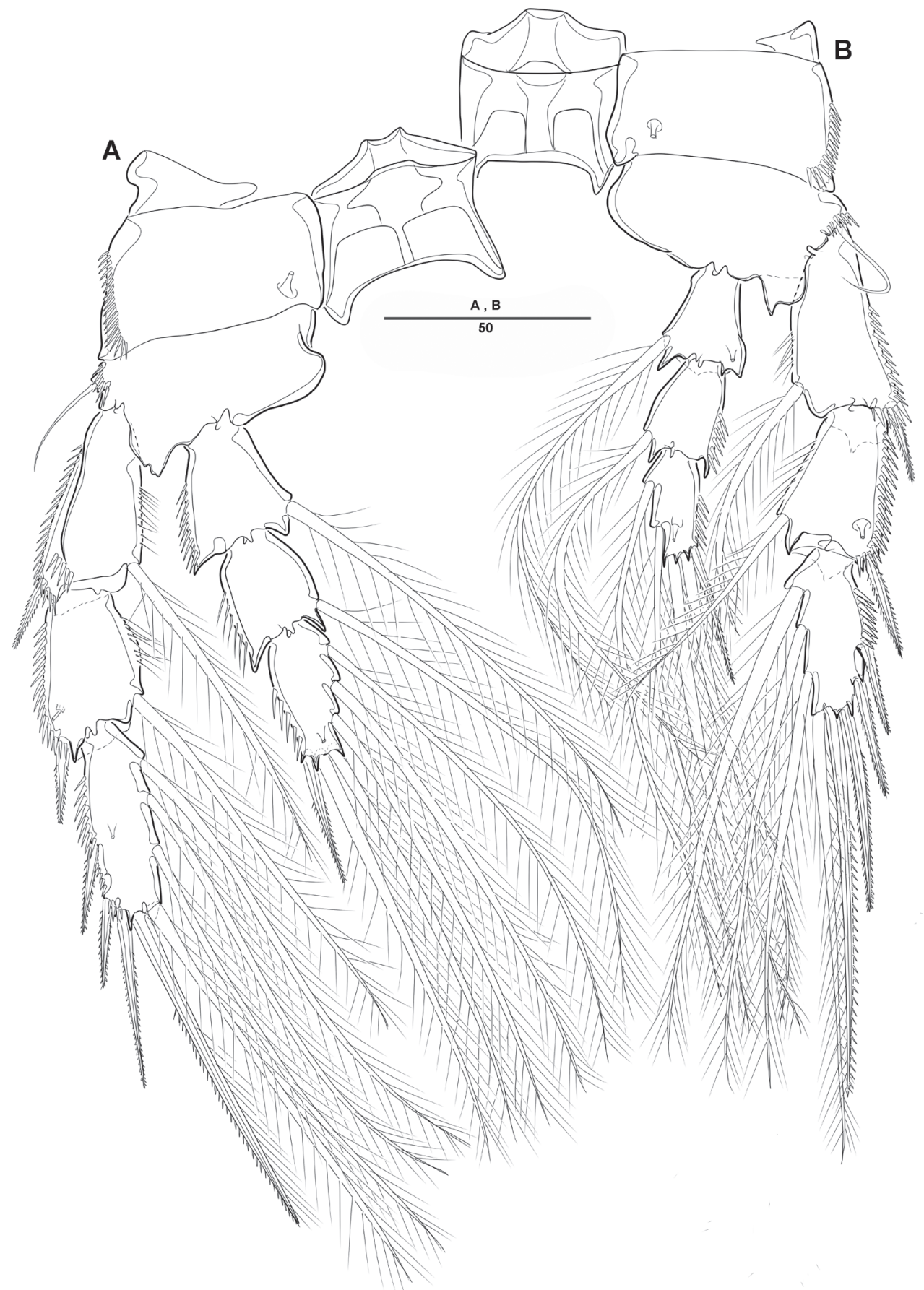

Figure 13. Parathalestris verrucosa Itô, 1970, female A third thoracopod B fourth thoracopod. Scale bars indicate length in $\mu \mathrm{m}$. 


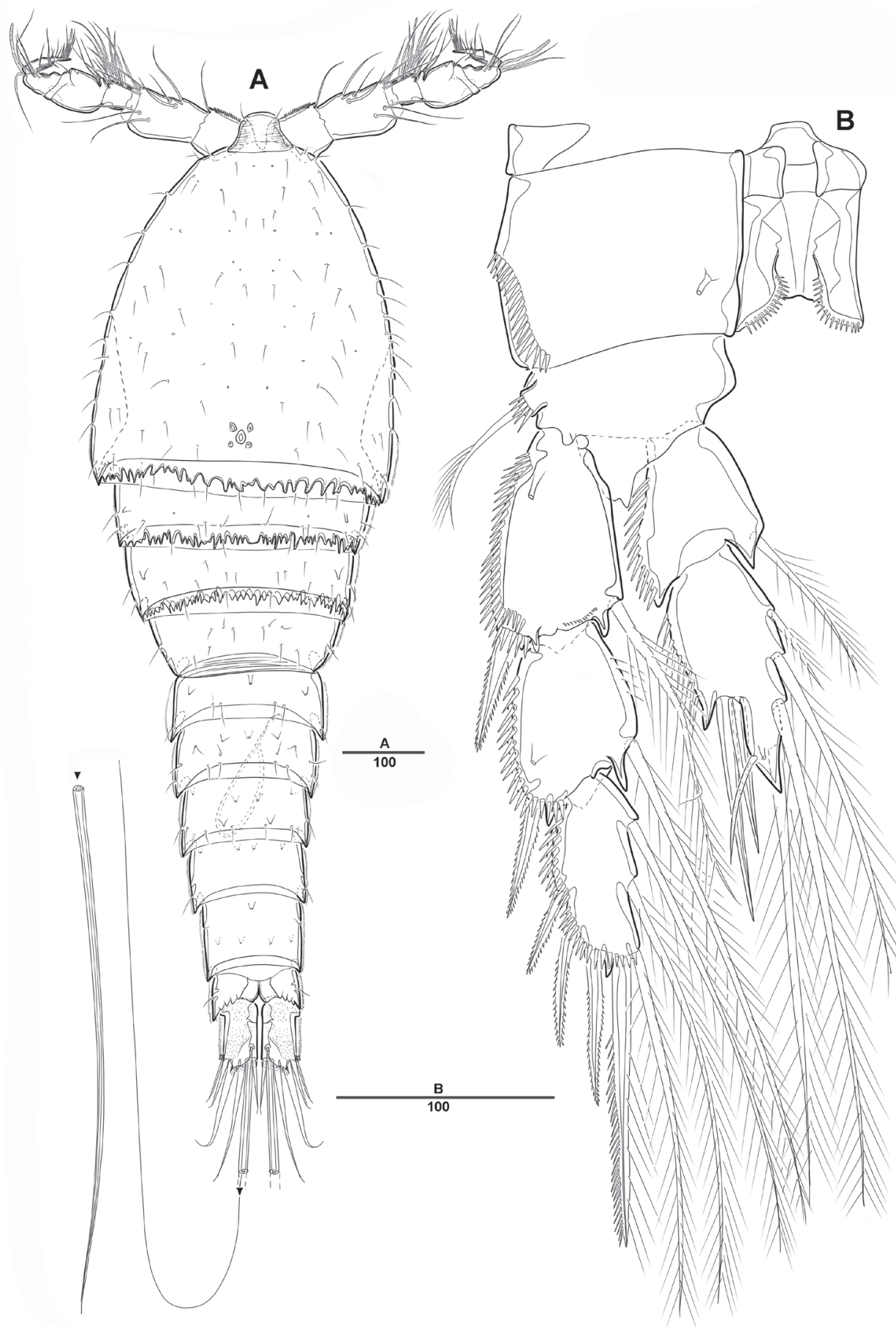

Figure 14. Parathalestris verrucosa Itô, 1970, male A habitus, dorsal B second. Scale bars indicate length in $\mu \mathrm{m}$. 


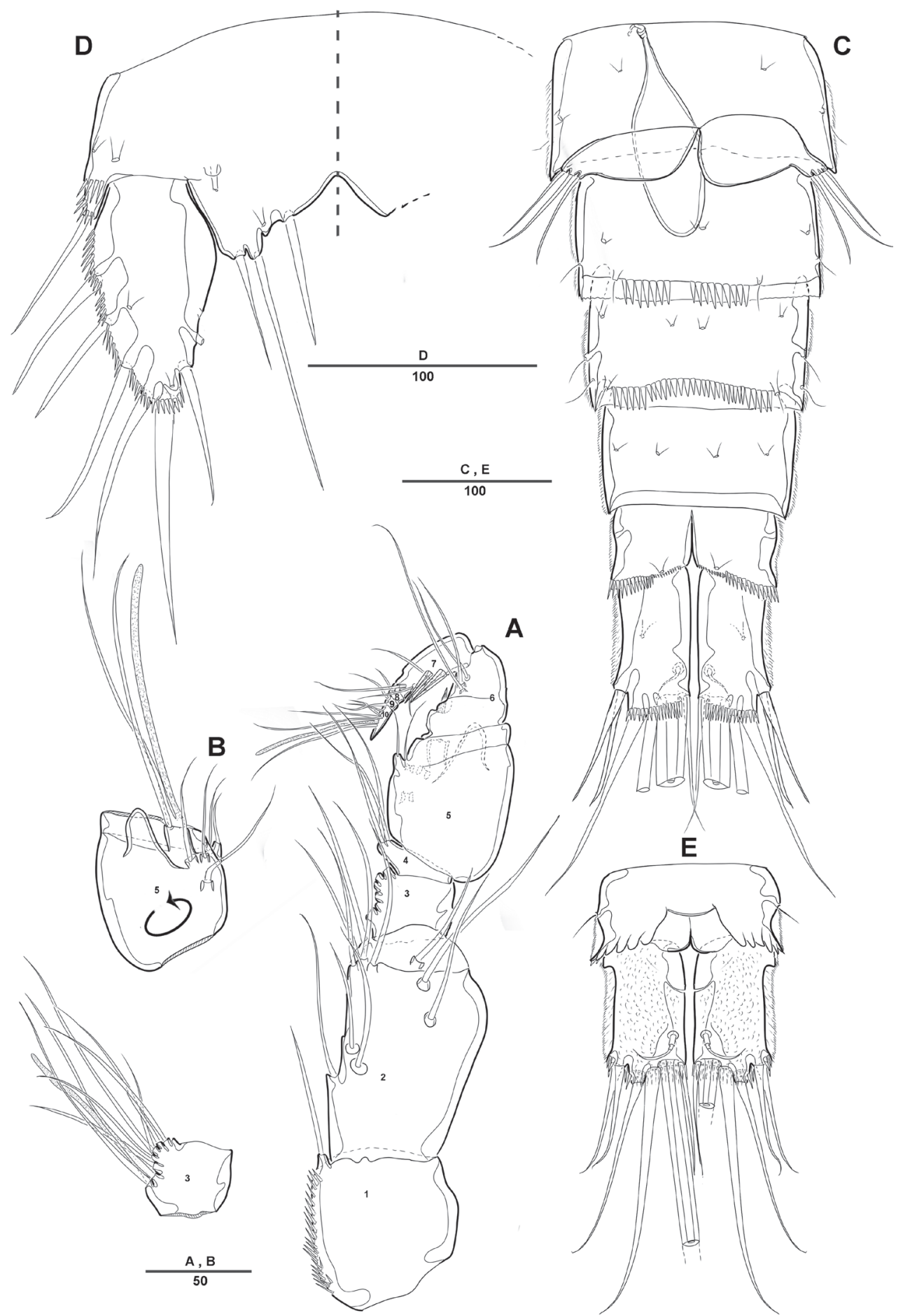

Figure I 5. Parathalestris verrucosa Itô, 1970, male A antennule B antennule segments 3 and 5 C urosomites, ventral D fifth thoracapod $\mathbf{E}$ caudal rami, dorsal. Scale bars indicate length in $\mu \mathrm{m}$. 


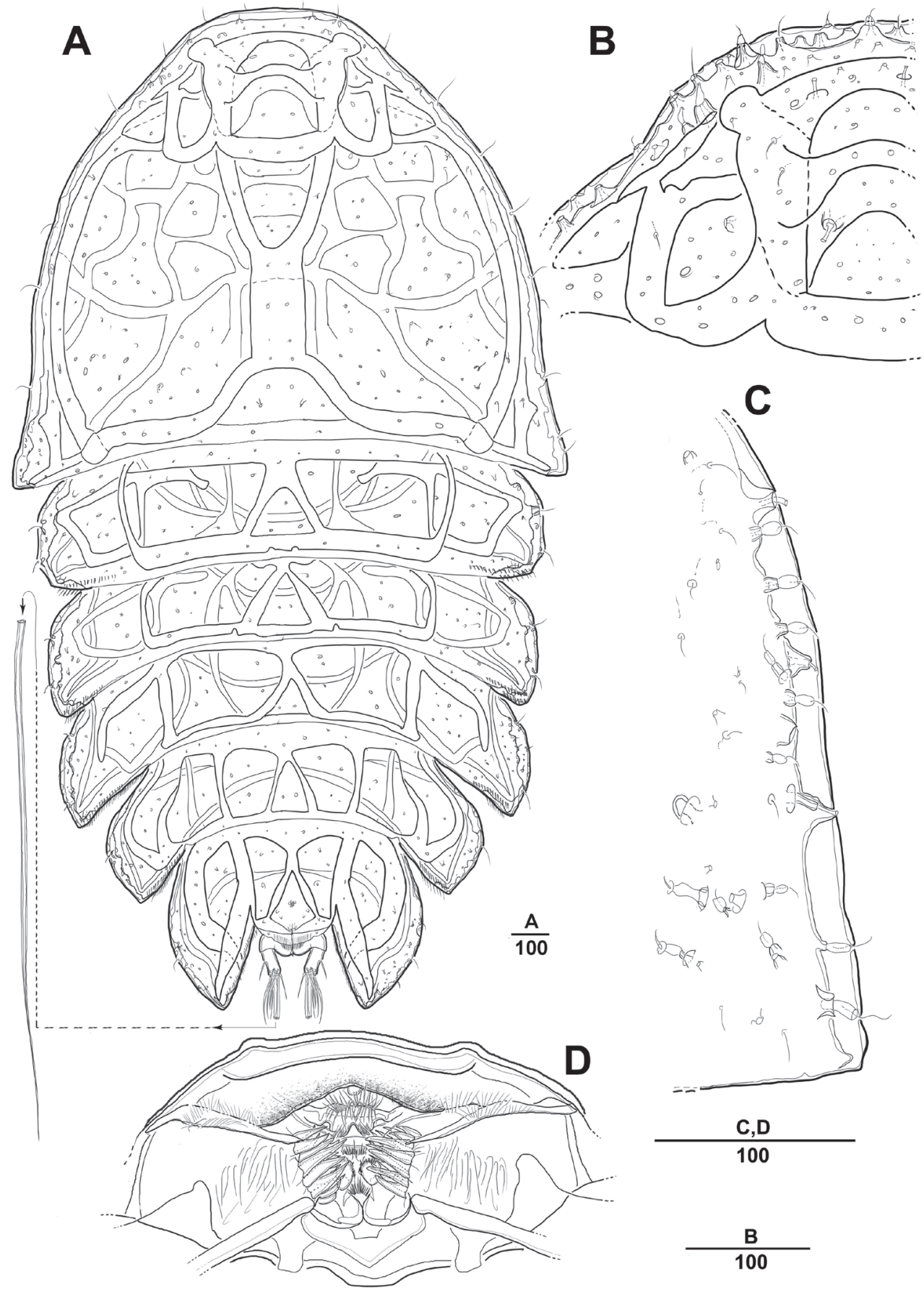

Figure 16. Peltidium quinquesetosum Song \& Yun, 1999, female A habitus, dorsal B anterior tip of cephalic shield $\mathbf{C}$ lateral margin of cephalic shield $\mathbf{D}$ rabrum. Scale bars indicate length in $\mu \mathrm{m}$. 


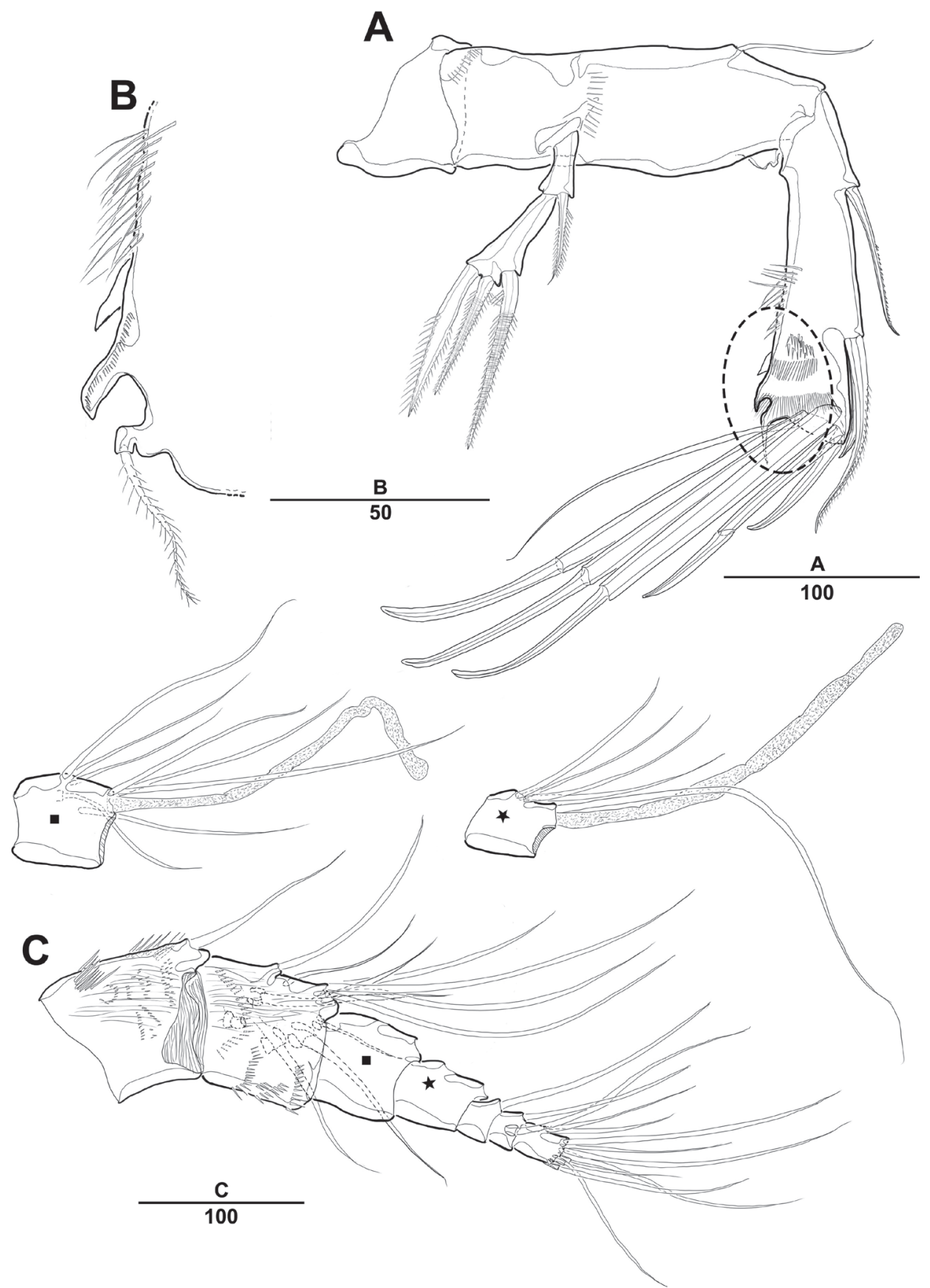

Figure 17. Peltidium quinquesetosum Song \& Yun, 1999, female A antenna B end of antennary endopod C antennule. Scale bars indicate length in $\mu \mathrm{m}$. 


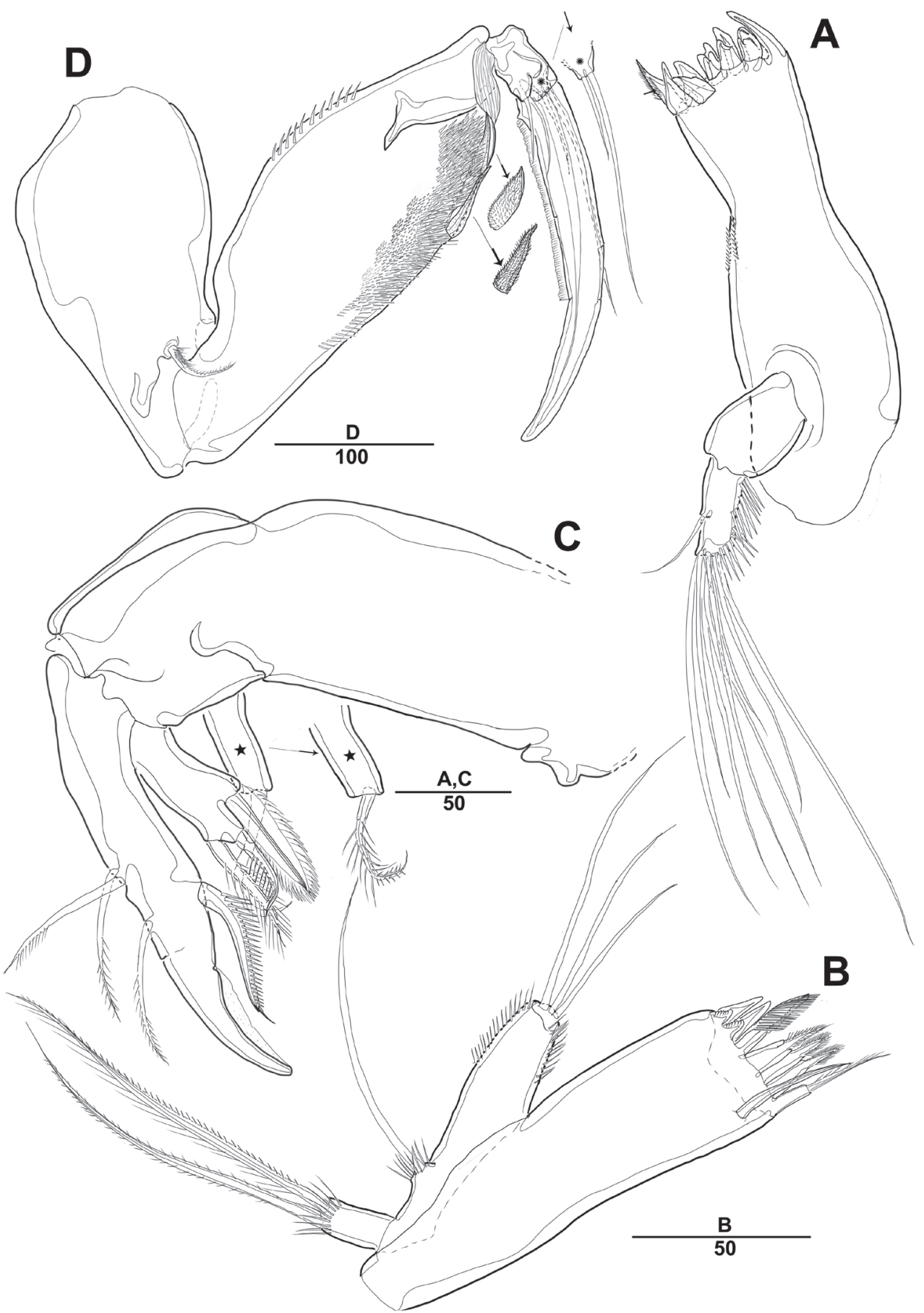

Figure 18. Peltidium quinquesetosum Song \& Yun, 1999, female A mandible B maxillule C maxilla D maxilliped. Scale bars indicate length in $\mu \mathrm{m}$. 


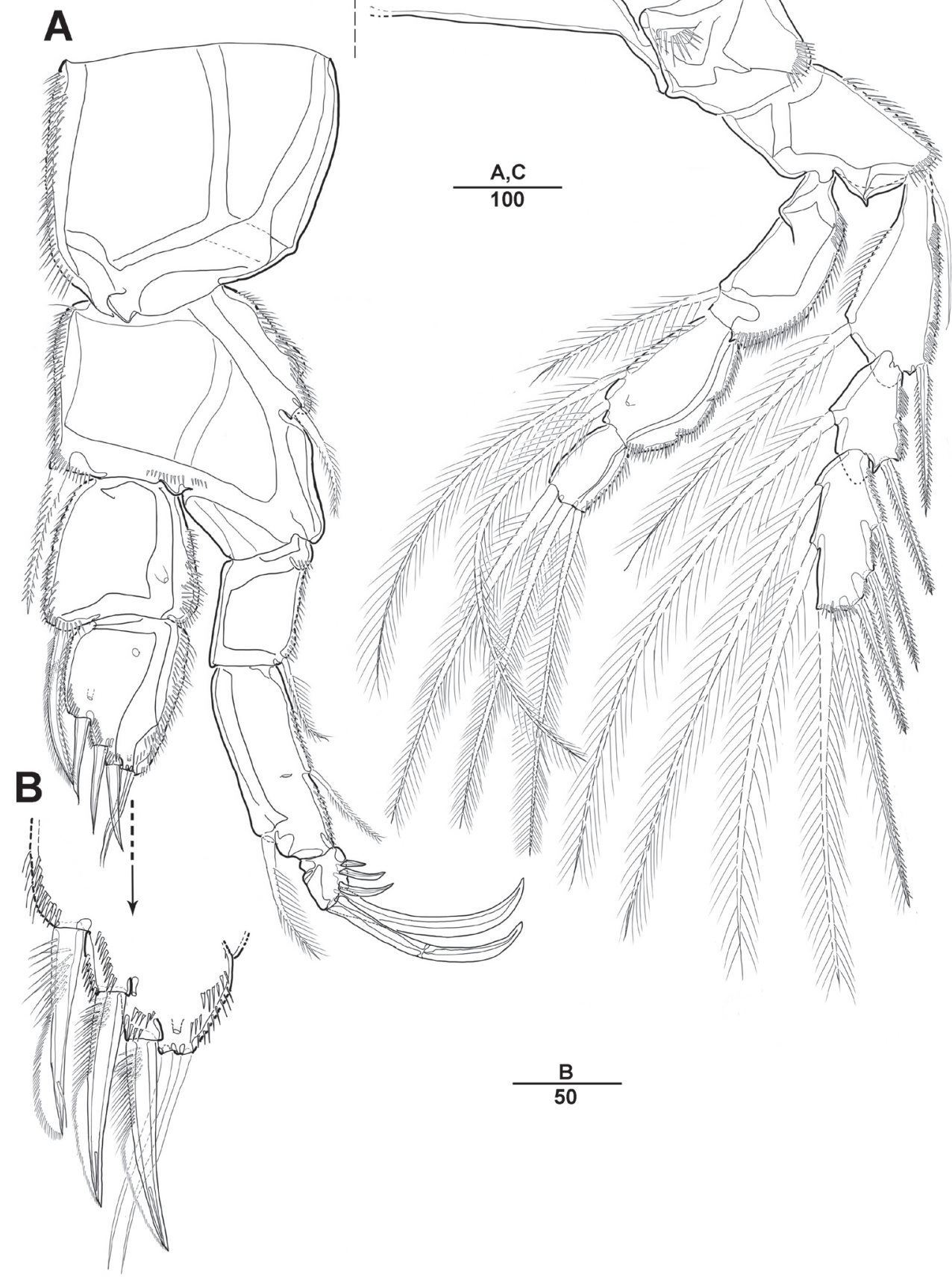

Figure 19. Peltidium quinquesetosum Song \& Yun, 1999, female A first thoracapod B shape of setae on second endopod in first thoracapod $\mathbf{C}$ second thoracapod. Scale bars indicate length in $\mu \mathrm{m}$. 


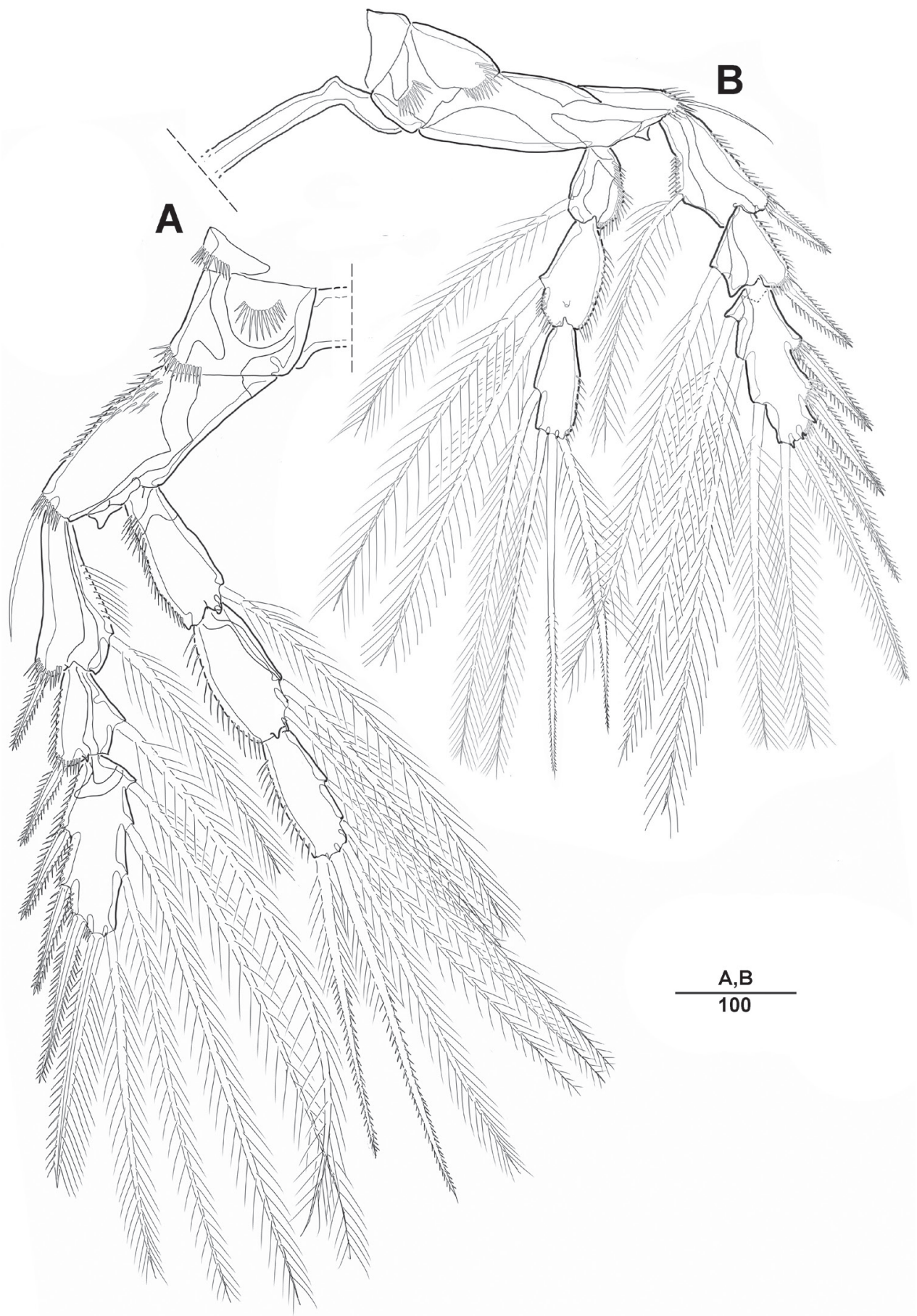

Figure 20. Peltidium quinquesetosum Song \& Yun, 1999, female A third thoracapod B fourth thoracapod. Scale bars indicate length in $\mu \mathrm{m}$. 


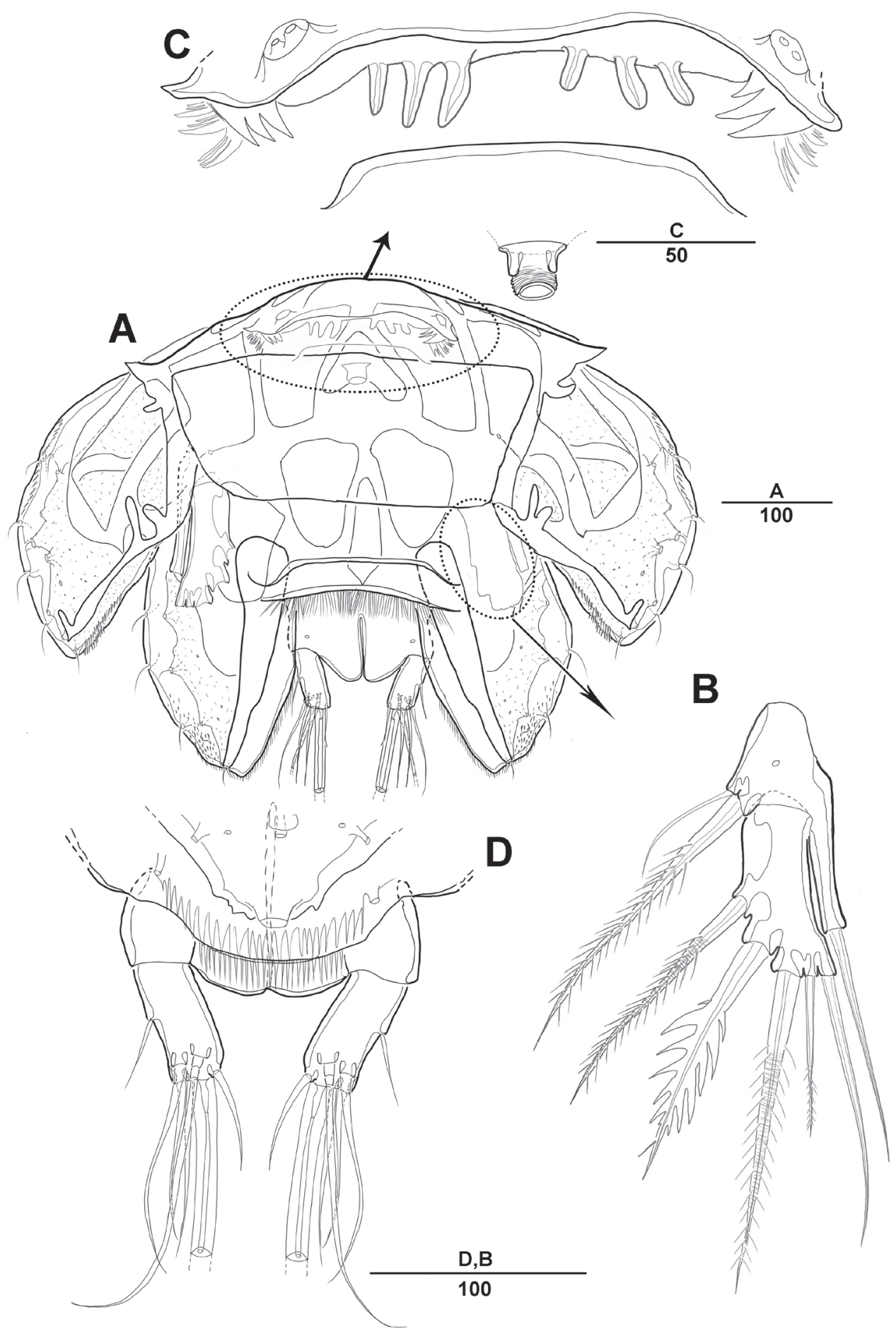

Figure 21. Peltidium quinquesetosum Song \& Yun, 1999, female A urosomites, ventral B fifth thoracapod $\mathbf{C}$ genital field $\mathbf{D}$ caudal rami, dorsal. Scale bars indicate length in $\mu \mathrm{m}$. 


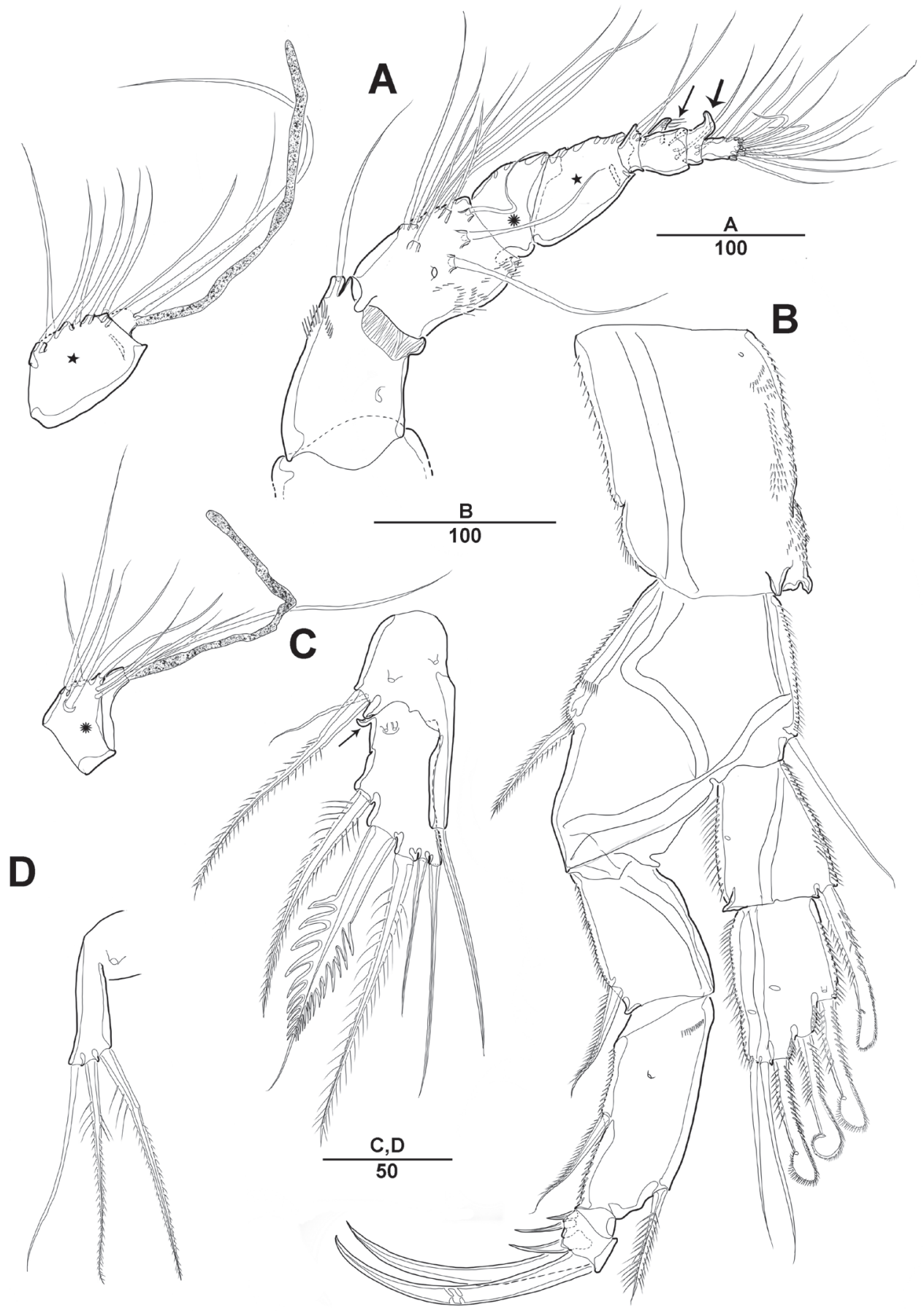

Figure 22. Peltidium quinquesetosum Song \& Yun, 1999, male A antennule B first thoracapod C fifth thoracapod $\mathbf{D}$ sixth thoracapod. Scale bars indicate length in $\mu \mathrm{m}$. 
Itô, 1974, based on the setae formula of the swimming legs, mouthpart structures, and the shapes of P5 and P6. However, the new species was also clearly distinguishable from D. ezoensis based on the length of the second inner seta on the P5 exp (obviously longest in the female) and the presence of long setules along the outer margin of the P2 enp-3, as previously noted by Song et al. (1999). In addition, the present study found that $D$. koreanus sp. nov. could be further distinguished on the basis of caudal seta VII, which was located halfway from the rami base (vs. on anterior extremity in D. ezoensis), and P6 with 3 setae in the female (vs. 2 setae in D. ezoensis).

The genus Diosaccus currently contains 14 valid species (Bodin 1997; Wells 2007), one of which includes two subspecies and two of which are only placed in the genus provisionally. In addition, the latest dichotomous key (Lang 1965) for the genus used doubtful characters, like moderate length seta and the length of caudal rami, based on old manuscripts, and the tabular keys provided by Wells (2007) also include suspicious characters, such as the relative length between P1 enp-2 and enp-3, mainly owing to the lack of information about the species. Therefore, an updated key, which includes $D$. koreanus sp. nov., is presented below. Attempts were made to update the key on the basis of accurate characters. However, this was difficult because most of the original papers did not include full descriptions of the species. Because there is no apparent differentiation between $D$. hamiltoni and $D$. tenuicornis females, a single male character was added to the key. For species recorded before 1948 refer to the description of Lang (1948).

\section{Key to Diosaccus species, based mainly on female specimens}

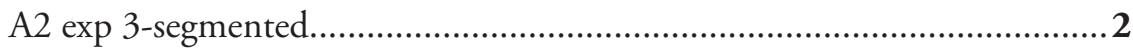

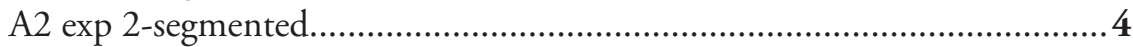

A2 exp 1-segmented........................................................................ 7 P1 enp-2 without inner seta; basis of mxp robust.... D. rebus (Sewell, 1940) Specimen without this combination of characters ...................................... 3 Basis of mxp slender; P1 enp-3 longer than enp-2; P1 enp-2 with 1 inner seta ............................................................................... valens (Gurney, 1927) Base of mxp robust; P1 enp-3 as long as enp-2; P1 enp-2 without inner seta..... D. robustus (Thompson \& Scott, 1903) Seg-3 and seg-4 with sharp dorsal teeth; P5 exp with 7 setae; benp with 5 spines, nearly equal in length D. dentatus (Thompson \& Scott, 1903) Specimen without this combination of characters P1 enp 2-segmented D. varicolor biarticulatus (Monard, 1924) P2 enp 3-segmented P5 exp with 6 setae D. varicolor varicolor (Farran, 1913) P5 exp with 5 setae D. varicolor pentasetosus (Noodt, 1955) P1 enp 2-segmented D. monardi Sewell, 1940 P1 enp 3-segmented 


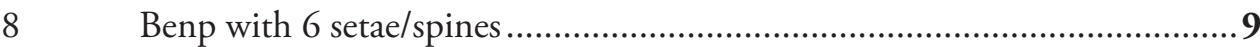

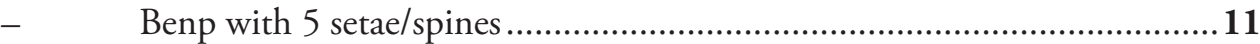

9 Caudal seta VII on proximally, P5 with 6 uniform (in length) setae, P6 with 2 setae

D. ezoensis Itô, 1974

- Specimen without this combination of characters .....................................10

10 Second outer seta on P5 benp longest ......... D. borborocoetus Jakobi, 1954 P5 benp with 6 spines D. koreanus sp. nov.

11 P5 benp with 5 spines 12

- $\quad$ P5 benp with 5 spines/setae 13

12 Second outer seta on P5 benp longest; caudal seta II slender

D. spinatus Campbell, 1929

First and second outer setae on P5 benp equal in length; caudal seta II strong

D. truncates Gurney, 1927

13 P2 exp-3 with 3 outer spines; $\delta$ P5 benp with 2 setae, inner seta longer than outer seta D. hamiltoni (Thompson \& Scott, 1903)

- $\quad$ P2 exp-3 with 2 outer spines; $\widehat{\jmath}$ P5 benp with 2 same length setae

D. tenuicornis (Claus, 1863)

\section{Non-destructive DNA extraction and identification}

The classification of harpacticoids has, until now, been primarily based on adult morphology, especially that of females. Significant differences between species, such as differences in number of segments or setae, are very important and recognizable characteristic that can be used to detect new species. However, some groups require researchers to classify species by features that are difficult describe, such as the widthto-length ratio of appendages, angle of segment inclination, and seta location. In addition, most of the recently discovered cryptic species are morphologically similar to known species. Although meiofauna are difficult to describe, owing to their small, fragile bodies, which make it difficult to obtain large amounts of genomic DNA from individual wild specimens (Sands et al. 2008), DNA sequencing can help with classification. The information about DNA sequences obtained from correctly classified species allows other researchers, for example, ecologists and researchers concerned with invasive species (Garrick et al. 2004) to quickly and easily classify species, even if they lack taxonomic knowledge. The use of DNA sequencing to identify and distinguish among cryptic species also allows taxonomists to identify more accurately taxonomically informative characteristics.

Previously identified harpacticoid species were described on the basis of morphological characteristics, not molecular ones. To classify benthic harpacticoids, observation is usually necessary under a high-power microscope. In this process, DNA in the specimen is destroyed by prolonged microscopic observation and the use of toxic media. Until now, it was difficult to get the DNA sequence and morphological information using same specimen. Therefore, there may be cases of incorrect registration of 
genetic information for other species. As in the present study and in Cornils (2015), the use of genetic information can reduce the error of species identification. However, specimen vouchers must be preserved for both the verification of genetic sequences and for morphological studies. The present study did not use genetic information for the phylogenetic analysis because the purpose of the study was to match accurately morphological features with the genetic information for each harpacticoid species. For an accurate phylogenetic study based on molecular and morphological data more species belonging to family Miraciidae are needed.

\section{Acknowledgments}

The authors are indebted to Dr Sahar Khodami and Dr Sven Rossel (Senckenberg am Meer Wilhelmshaven, Germany) for reviewing the manuscript and providing helpful and constructive critics and comments. This work was supported by grants from the National Marine Biodiversity Institute of Korea (2020M00100).

\section{References}

Back J, Lee W (2011) Redescription of two species of Parathalestris (Copepoda, Harpacticoida, Thalestridae) in Korea. Bulletin of National Institute of Biological Resources 2: 85-97.

Beheregaray LB, Caccone A (2007) Cryptic biodiversity in a changing world. Journal of Biology 6: 9. https://doi.org/10.1186/jbiol60

Bhadury P, Austen MC, Bilton DT, Lambshead PJD, Rogers AD, Smerdon GR (2006) Development and evaluation of a DNA-barcoding approach for the rapid identification of nematodes. Marine Ecology Progress Series 320: 1-9. https://doi.org/10.3354/meps320001

Bodin P (1997) Catalogue of the new marine harpacticoid copepods (1997 Edition). Documents du travail de l'Institut Royal des Sciences Naturelles de Belgique 8: 1-304.

Chang CY (2007) Two harpacticoid species of genera Nitokra and Ameira (Harpacticoida: Ameiridae) from brackish waters in Korea. Integrative Biosciences 11: 247-253. https:// doi.org/10.1080/17386357.2007.9647341

Chang CY, Song SJ (1997) Marine harpacticoids of genus Parathalestris (Copepoda, Harpacticoida, Thalestridae) from Korea. The Korean Journal of Systematic Zoology 13: 221-231.

Cornils A (2015) Non-destructive DNA extraction for small pelagic copepods to perform integrative taxonomy. Journal of Plankton Research 37: 6-10. https://doi.org/10.1093/plankt/ fbu 105

DeSalle R, Goldstein P (2019) Review and interpretation of trends in DNA barcoding. Systematic review. Frontiers in Ecology and Evolution 7: 1-11. https://doi.org/10.3389/ fevo.2019.00302

Edgar RC (2004) MUSCLE: multiple sequence alignment with high accuracy and high throughput. Nucleic Acids Research. 32(5): 1792-1797. https://doi.org/10.1093/nar/ gkh340 
Folmer O, Black M, Hoeh W, Lutz R, Vrijenhoek R (1994) DNA primers for amplification of mitochondrial cytochrome c oxidase subunit I from diverse metazoan invertebrates. Molecular Marine Biology and Biotechnology 3: 294-299.

Garrick RC, Sands CJ, Rowell DM, Tait NN, Greenslade P, Sunnucks P (2004) Phylogeography recapitulates topography: very fine-scale local endemism of a saproxylic 'giant' springrail at Tallagranda in the Great Dividing Range of south-east Australia. Molecular Ecology 13: 3315-3330. https://doi.org/10.1111/j.1365-294X.2004.02340.x

Hebert PDN, Cywinska A, Ball SL, deWaard JR (2003) Biological identifications through DNA barcodes. Proceeding of Royal Society of London B 270: 313-321. https://doi. org/10.1098/rspb.2002.2218

Huys R, Gee JM, Moore CG, Hamond R (1996) Synopses of the British Fauna (New Series) No. 51. Marine and Brackish Water Harpacticoids, Part 1. Field Studies Council, Shrewsbury, $352 \mathrm{pp}$.

Itô T (1970) Descriptions and records of marine harpacticoid copepods from Hokkaido, III. Annotationes Zoologicae Japonenses 43: 211-218.

Itô T (1974) Descriptions and records of marine harpacticoid copepods from Hokkaido, V. Journal of the Faculty of Science, Hokkaido University, Series VI, Zoology 19: 546-640.

Jakobi H (1954) Harpacticoida (Cop. Crust.) da microfauna do substrato areno-lodoso do "Mar de Dentro" (Ilha do Mel - Bais de Paranaquá - Brasil). Dusenia 5: 209-232.

Karanovic T, Lee S, Lee W (2018) Instant taxonomy: choosing adequate characters for species delimitation and description through congruence between molecular data and quantitative shape analysis. Invertebrate Systematics 32: 551-580. https://doi.org/10.1071/IS17002

Kearse, M, Moir R, Wilson A, Stones-Havas S, Cheung M, Sturrock S, Buxton S, Cooper A, Markowitz S, Duran C, Thierer T, Ashton B, Meintjes P, Drummond A (2012) Geneious Basic: An integrated and extendable desktop software platform for the organization and analysis of sequence data. Bioinformatics 28: 1647-1649. https://doi.org/10.1093/bioinformatics/bts199

Kim JG, Jung TW, Yoon SM (2015) First record of the genus Halectionosoma (Copepoda: Harpacticoida: Ectinosomatidae) with Redescription of $H$. perforatum from Korea. Korean Journal of Environmental Biology 33: 132-139. https://doi.org/10.11626/ KJEB.2015.33.2.132

Kim K, Park E, Lee W (2011) First record of Onychostenhelia bispinosa (Copepoda: Harpacticoida: Miraciidae) from Korea. Bulletin of National Institute of Biological Resources 2: $55-65$.

Lang K (1948) Monographie der Harpacticiden. Håkan Ohlsson, Lund, 2: 1682 pp.

Lang K (1965) Copepoda Harpacticoidea from the Californian Pacific coast. Kunglieren svenska Vetenskapsakademiens Handlingar 10: 1-560.

Noodt W (1955) Marine Harpacticoiden (Crust. Cop.) aus dem Marmara Meer. Istanbul Üniversitesi Fen Fakültesi mecmuasi 20B: 49-94.

Park EO, Han MS, Lee W (2012) The first record of Orthopsyllus species (Copepoda: Harpacticoida: Orthopsyllidae) from Korean waters. Journal of Species Research 1: 56-67. https:// doi.org/10.12651/JSR.2012.1.1.056 
Sands CJ, Convey P, Linse K, McInnes SJ (2008) Assessing meiofaunal variation among individuals utilizing morphological and molecular approaches: An example using the Tardigrada. BMC ecology 8: 7. https://doi.org/10.1186/1472-6785-8-7

Song SJ, Park J, Kwon B-O, Ryu J, Khim JS (2012) Ecological checklist of the marine and brackish-water harpacticoid copepod fauna in Korean waters. Zoological Studies 51: 1397-1410.

Song SJ, Yun SG (1999) A new species of the Peltidium quinquespinosa (Copepoda: Harpacticoida: Peltidiidae) on the marine macroalgae in Korea. The Korean Journal of Systematic Zoology 15: 67-74.

Song SJ, Yun SG, Chang CY (1999) New records on three harpacticoid copepods associated with marine macroalgae in Korea. Journal of Fisheries Science and Technology 2: 189-198.

Tamura K, Nei M (1993) Estimation of the number of nucleotide substitutions in the control region of mitochondrial DNA in humans and chimpanzees. Molecular Biology and Evolution 10: 512-526.

Vakati V, Eyun S-I, Lee W (2019) Unraveling the intricate biodiversity of the benthic harpacticoid genus Nannopus (Copepoda, Harpacticoida, Nannopodidae) in Korean waters. Molecular Phylogenetics and Evolution 130: 366-379. https://doi.org/10.1016/j. ympev.2018.10.004

Wells JBJ (2007) An annotated checklist and keys to the species of Copepoda Harpacticoida (Crustacea). Zootaxa 1568: 1-872. https://doi.org/10.11646/zootaxa.1568.1.1

Yamaguchi S (2003) Morphological evolution of cytherocopine ostracods inferred from $18 \mathrm{~S}$ ribosomal DNA sequences. Journal of Crustacean Biology 23: 131-153. https://doi. org/10.1163/20021975-99990322 